\title{
Yeni Bağlamlarında Devam Eden Sorunlar: Dijital Kapitalizm ve Kullanıcı Emeğini Yeniden Düșünmek Üzerine
}

\author{
Serhat Kaymas ${ }^{1}$
}

Özet

Sosyal Bilimlerde yeni zamanlar, kısmen yeni yöntemleri ve bakış açılarını çağırmakta iken kısmen de var olan ya da süre giden tartışmalara yeniden bir değer biçme çabasını teşvik etmektedir. Bu çalışma içerisinde, söz konusu ikinci yaklaşım belirlenmiştir. Eleştirel ekonomi politik yaklaşımın genel bir değerlendirmesinin ardından, maddi olmayan emek, eleştirel ekonomi politik yöntem içerisinde yeniden sorgulanmaktadır. Yeni enformasyon ve iletişim teknolojileri söz konusu olduğunda, kullanıcı emeğinin ve emeğin dönüşümünün sorgulanması özel bir çalışma geleneği oluşturmuşsa da, en azından, Türkiye'de süre giden iletişim çalışmalarının bu doğrultuda da yeniden değerlendirilmesi gerekmektedir. Bu çalışma içerisinde kullanıcı emeği, Ekşi Sözlük örneğinde çözümlenecektir. 28 Şubat 2016 tarihinde başlayan, bu çalışma içerisinde sürecin bir aylık döneminin değerlendirildiği, Ekşi Sözlük direnişi aslında oldukça temel bir düzeyde sosyal paylaşım siteleri ve kullanıcı emeği arasındaki ilişkinin tartışılabilmesi adına oldukça anlamlı bir kesit sunmaktadır. Sosyal paylaşım siteleri içerisinde kullanıcı emeğinin sermaye birikim süreci doğrultusunda "işe koşulmasının" yanı sıra Sözlük yönetiminin, site tasarımını ve kullanıcılarla olan sözleşmelerini tek taraflı olarak değiştirmesinin kullanıcılar içerisinde oluşturduğu hoşnutsuzluk, yeni enformasyon ve iletişim teknolojileri içerisinde kullanıcı emeğine dair çalışmaların yeniden sorgulanabileceği özel bir alan açmıştır. Bu çalışmada Ekşi Sözlük direnişi örneğinde kullanıcı emeği ve emeğin dönüşümü sorgulanmaktadır. Kuramsal tartışmanın ardından, Ekşi Sözlük direnişi ele alınmaktadır. Böylesi bir değerlendirme içerisinde, sermaye ve emek arasındaki diyalektik çözümlenmiş ve yeni ön eki ile tanımlanmasına rağmen, kadim sorunların yeni medyada nasıl yer edinebildiği sorgulanmıştır.

Anahtar Sözcükler: Yeni Enformasyon ve İletişim Teknolojileri, İzleyici tarafından Üretilen İçerik, Ekşi Sözlük.

\section{Ongoing Problems in Their New Context: On Rethinking of Digital Capitalism and User Labour Nexus}

\begin{abstract}
New times in the social sciences sometimes call for promotion of new methods and approaches while sometimes encourage the reappraisal and promotion of the ongoing debates and approaches. This study focuses on the second approach. Following an overview of the critical economy politics approaches; this study is expanded on the capital and immaterial labour relations via the case study of "Ekşi Sözlük" experiences within the bounded debates on critical political economy of the media. When the
\end{abstract}


new information and communication technologies, which deal especially with the informational capitalism, are concerned, although questioning the user labour and its transformation results in a well-established working tradition, the efforts on the ongoing studies regarding the communication in Turkey must at least be re-evaluated in this context. In this study, the nexus of using labour and its transformation in the context of new information and communication technologies is being analysed via the case study of Ekşi Sözlük, especially the protest of the writers of the Ekşi Sözlük after February 28, 2016. Ekşi Sözlük resistance, which started on February 28, 2016, actually provides a meaningful context on the inside of the basic level of social networking sites and user labour relationships and of course the transformation of the user-labour context. This study herein covers a one-month period after the start of Ekşi Sözlük resistance. Indeed, in accordance with the process of capital accumulation in the social networking sites and especially the real conditions of the user-labour's "working conditions" as well as the ownership's control, site design and in this regard discontent in which Ekşi Sözlük's generated by the contract with users in the user's unilateral modification, may be questioned again on the work of the user-labour, user generated content, within the new information and communication technologies' designed special imperatives. In this study, these aspects and conditions of the social networking sites are investigated via the case study of Ekşi Sözlük's resistance. In an effort, such as preparing this study, at least an initial level can be evaluated as a meaningful attempt for the analysis on the media's critical political economy, in this context, ownership and labour dialectics. In this way, although the new information and communication technologies are defined by the "new" prefix, how the "ancient" ongoing problems, such as user-labour and its transformation in the new context, are handled is a meaningful research area, especially at the heart of the information society thesis. This study is an attempt for the analysis of these "ancient" problems in the new context.

Keywords: New Information and Communication Technologies, User Generated Content, Ekşi Sözlük. 


\author{
"Sermayenin getiri oranı, üretim ve gelirin \\ büyüme oranını aştığında-ki 19. yüzyılda \\ durum buydu ve 21. yüzyılda da gerçekleşme \\ olasılığı oldukça yüksektir- kapitalizm \\ demokratik toplumların dayandığı meritokratik \\ değerleri derinden sarsan, rastgele ve \\ sürdürülemez eșitsizlikleri otomatik olarak \\ üretmeye başlar" (Piketty, 2014:2).
}

\title{
Giriș
}

Y eni enformasyon ve iletişim teknolojilerinin, emeğin dönüşümü üzerine olan etkisi nasıl çözümlenebilir? Kapitalizmin enformasyonu metalaştırarak kurduğu yeni birikim modeli içerisinde emek ve emeğin dönüşümü; bütün bir tarihi içerisinden bakıldığında sermaye birikim koşullarındaki değişimi yansıtan bir parçalanmayı mı, çelişkili de olsa bir sürekliliği mi temsil etmektedir? Kapitalizm, yukarıdaki alıntıda da sorgulandığı üzere, demokratik bir toplumun değerlerini keskin bir biçimde sarsan eşitsizlikleri kendi içerisinde nasıl yeniden üretmektedir? Bu çalışma, iletişimin eleştirel ekonomi politik yaklaşımı içerisinde belirlenen kuramsal uzam içerisinde, söz konusu sorulara dair bütüncül bir yanıt oluşturmayı amaçlamıştır. Bu doğrultuda çalışma; kapitalizmin bu kez yeni bir aşamasında kullanıcı emeğini ve emeğin dönüşümünü, 28 Şubat 2016 tarihinde başlayan Ekşi Sözlük "direnişinin” bir aylık dönemi örneğinde, okumaktadır. Ancak böylesi bir okuma, kapitalizmin yalnızca yeni birikim modeli içerisinden değil aksine bizatihi bütün bir tarihi içerisinden bakarak sermaye ve emek diyalektiğini anlamlandırmaya dair açık bir çağrıyı oluşturmaktadır. Her ne kadar bu çalışma, maddi olmayan emeğe dair kuramsal bir okuma çabası olarak görülse ve maddi olmayan emeğe dair gittikçe artan bir ilginin beslediği tartışmalar dizgesi içerisinde çalışmanın sesinin "boğulma" tehlikesi olsa dahi, gerçekte bu çalışmanın iki önemli açıdan yenilikçi olduğu söylenmelidir. Gerçekten de, bu çalışma aşağıda da açıklanacağı üzere kapitalist sermaye birikim koşullarındaki dönemsel değişimlere koşut olarak değil aksine sermaye ve emek ilişkisini kapitalist birikim modellerinin kendi içerisinde, çelişkili de olsa, süreklilik içeren yapısı içerisinde okumayı amaçlamıştır. İlkel sermaye birikiminin ve mülkiyetin gasp edilmesi üzerinden sermaye birikiminin araçsallaştırdığı emeği yeniden tartışmak bu açıdan anlamlı bir çaba olarak değerlendirilmelidir.

Ekşi Sözlük site yönetiminin, yazarlarına bilgi vermeden yeni bir sözleşmeyi bir bakıma "zorunlu" kılması ve yeni hükümleri uygulamasının ardından sitenin yazarları tarafından gerçekleştirilen direniş süreci, ilerleyen kısımlarda ayrıntılı olarak değerlendirileceği üzere, kapitalizmin yeni sermaye birikim modeli ve emek arasındaki ilişkinin okunabilmesi için özel bir kesit açmıştır. Hatta yeni enformasyon ve iletişim teknolojileri içerisinde kullanıcı tarafından üretilen içeriğin, neredeyse bir tür "eğlence" olduğu bu nedenle de herhangi bir mübadele değeri üretemeyeceği yönündeki görüşlerin ve tartışmaların yeniden ele alınmasını da gerektiren sürecin bu direniş üzerinden açıldığı açıktır. Yeni birikim rejimi içerisinde kurulan emek ve sermaye ilişkisinin, öncesi olmayan bu yönüyle de bir uçtan diğer uca sürüklenen tamamen yeni bir dinamik oluşturmaktan çok, çalışmanın isminde de yer aldığı gibi, bu kez "yeni bağlamlarında" üretilen kadim sorunlara işaret ettiğinin söylenmesi kendi içerisinde bütüncül ve anlamlıdır. Kapitalist üretim, birikim ve bölüşüm rejimini kendi bütünselliği içerisinde ele almak aslında açık 
bir çağrı oluşturmaktadır. Marx'ın (2013:686-689), kapitalist birikim rejimi içerisinde, üreticilerin bu kez ücretli, hatta bu çalışmada tartışılması amaçlandığı üzere yeni enformasyon teknolojilerinde ücretsiz, emekçilere dönüştüren "ilk günahın" izlerini yeni bir bağlamda öncesi olmayan bir biçimde değerlendirmek yerine bu ilişkiyi dönüştüren toplumsal ilişkiler ağının oluşturduğu bağlamı değerlendirmek gerekir. Kapitalist birikim rejimi içerisinde böylesi bir bütünselliği değerlendirmemek aslında yanlıș tanımlanmış bir "iktidarsız ideoloji” denkleminin miyopisini yeniden üretir. Gerçekten de; maddi olmayan emeği yalnızca kapitalizmin bir dönemi ile ilgili olarak ele alan ve tartışmalarını tam da böylesi bir kesit içerisinde sınırlandıran çalışmaların, bütün bir tarihi içerisinde kapitalizmin emeği biçimlendirme ve yeniden inşa etme gücünü oldukça sınırlı olarak değerlendirdiği söylenmelidir. Bu çalışma içerisinde; "maddi olmayan emek" tartışmasını kendi içerisinde tutarlı ve kuramsal bir bağlam içerisinde okumak amaçlandığı gibi, en azından Türkiye'de süre giden çalışmalar için, yeni bir tartışma boyutunun eklemlenmesi adına açık bir davetiye gönderisi olarak planlanmıştır. Böylesi bir çaba, en azından Türkiye'de süre giden çalışmalar için önemlidir. Çünkü kapitalizmin kendisini sabitlediği uğrakları, çelişkili bir süreklilik içerisindeki birikim modellerini, bu dinamikler içerisinde üretilen güç ve iktidarı değerlendirme dizgesine alarak ilerleyen ancak son kertede emeğe dönen çalışmaların odağını, bu kez "üretim güçleri” ve “üretim ilişkilerini” temel alarak, kırma çabası oldukça işlevseldir. Gerçekten de; kapitalizmi anlatma iddiasını; değişen ve dönüşen pratikleri içerisinde bir süreklilik olarak değil bizatihi tarihi ve ürettiği iktidar içerisinde birbiri ile "konuşmayan" bir metnin paragrafları, açık söylendiğinde birikim rejimlerini gittikçe kapitalizmin kendisinden dahi uzaklaşmış alanları, olarak okuyan çalışmaların emek ve dönüşümü ile yüzleşememe hali içerisinde olduğunu belirtmek gerekir. Gösteri toplumunun kendisini gerçekleştirme biçimini yeniden üreten denli "çok"laşan, maddi olmayan emeğe dair tartışmalar içerisinde, tam da böylesi bir ilk günahın yansımaları okunmaktadır. Gerçekten de, toplumsal ilişki ağını, el koyarak mülksüzleştirmeyi ve ilkel birikimi hiç de tartışmaksızın yalnızca yeni sermaye birikiminin emek için açtığı kesiti tartışmak en azından yalnızca yakını görebilen bir odak yanılsaması olsa gerektir. Mattias Ekman'ın (2014:85) söylediği gibi; "Marx'ın ilk/ilkel birikim kuramı, günlük çevrimiçi faaliyetler üzerine olan tartışmayla ilişkili olarak, Web 2.0'daki kültürel üretim, dağıtım ve iletişim alanındaki yaratıcılığa ve düşünsel ürünlere (intellectual assests) el koyma şeklindeki sömürünün" ancak yeni biçimlerini anlamayı sağlar. Bu doğrultuda, çalışma da tartışıımasının amaçlandığı üzere, iletişim çalışmaları içerisinde maddi olmayan emeğe yeniden bir değer biçme çabasının; öncelikli olarak, toplumsal ilişkiler ağını, ilkel birikim sürecini ve mülksüzleştirerek ya da daha farklı söylendiğinde emeğin ürünü gasp ederek gelişen sömürünün yeni biçimlerini düşünmesi gerekir.

\section{Araștırmanın Kuramsal Uzamı, Amaç ve Sınırlılıkları: Kuramı, Alanla Bütünleștirmek}

Çalışmanın odağında yer alan ve geleneksel medyanın egemen söylemlerine "direniş" olarak geçen Ekşi Sözlük yönetimi ve kullanıcıları arasındaki kırılmanın, medyanın eleştirel ekonomi politiğine dair bir çerçeve içerisinden bakılmasını gerektirdiği açıktır. Gerçekten de, Ekşi Sözlük "kırılması" en azından, maddi olmayan emek, ilkel birikim ve mülksüzleştirerek birikim olmak üzere, üç temel alanda önemli bir tartışma uzamı oluşturmaktadır. Çalışma; serbest emek, boş zaman etkinliği, eğlence gibi görülen ancak son kertede boş zamanın, benliğin ve hatta toplumsal ilişkilerin metalaştırılmasının yeni enformasyon ve iletişim teknolojilerinin politik ekonomisi içerisindeki "işlev"selliğini değerlendirmeyi bu yönüyle de aslında henüz yukarıda 
belirtilmiş olduğu gibi bir toplumsal ilişki ağı olarak kapitalizmin anlamlandırılabilmesini amaçlamaktadır. Çalışma; bu doğrultuda çözümlemesini üç ana alan üzerine yoğunlaştırmıştır: (1) Mülkiyetin hem ideolojik hem de sermaye birikim aracı olarak denetlediği alan olarak Ekşi Sözlük. (2) Ekşi Sözlük örneğinde "ücretsiz emek" ve yapılanma (3) Mülkiyet sahipleri ve yazarları arasındaki kriz döneminde Ekşi Sözlük ve yeniden yapılandırılması. Çalışma içerisinde amaçlanan tartışmanın sınırları oluşturmaktadır.

Çalışmanın, yeni enformasyon ve iletişim teknolojilerinde süre giden maddi olmayan emeğe dair yeniden bir değer biçme amacı; çözümleme içerisinde, kuramsal sürekliliğin gözlenebileceği bir alan olarak kuramsal birikime de yeniden ancak olabildiğince genel bir düzeyde dönülmesine yol açmaktadır. Ekşi Sözlük direnişinin, kamusal alanda nasıl yer edinebildiğine dair tartışma içerisinde metin analizi ve metinler arası bir okumayı gerekli kılmıştır. Maddi olmayan emeğin, bu çalışma içerisinde birbiri ile yakından ilgili iki boyut üzerinden düşünülebilecek bir kesitte ele alındığı söylenmelidir. Bu boyutların ilki, "kitle iletişiminin gerçek ürününün ne olduğu" ve ikincisi ise "kültürel üretimde değerin nasıl oluştuğunun" tartışılmasıdır. Tartışmanın bu kısmı, ağırlıklı olarak, Bourdieu sosyolojisi ${ }^{1}$ içerisinden kurulan bir çerçeve içerisinde ele alınacaktır. Sınıfı; gündelik yaşam pratikleri içerisindeki mücadele ekseninde anlamlandıran Bourdieu sosyolojisinin, yeni enformasyon ve iletişim teknolojileri içerisinde "değer" ve "metanın" yeniden değerlendirilebilmesi için anlamlı bir kesit açtığı belirtilmelidir. Fuchs (2016:156); "bu nedenle herhangi bir kişi medya tarafından ekonomik değer üretiminin, Bourdieu'nün sosyal, kültürel ve simgesel sermaye olarak isimlendirdikleriyle nasıl bağlandığına kafa yormalıdır. Çünkü belirli bir dereceye kadar, Bourdieu'nün (1986a, 1986b) sosyal sermaye (sosyal ilişkilerin birikimi), kültürel sermaye (bilgi, eğitim, vasıf birikimi) ve simgesel sermaye (itibar birikimi) olarak adlandırdıklarını başarmak için uğraşır" şeklinde değerlendirmektedir. Yeni enformasyon ve iletişim ağları özelinde bakıldığında, bir mübadele değeri oluşturacak denli genişleyen metalaştırma sürecinin tam da sermayenin birbirine dönüşümü olarak anlamlandırıması gerekir. Yeni enformasyon ve iletişim teknolojilerinin bu bağlamda yeni bir ekseni açtığı görülür. Geleneksel medyadaki izleyiciden yeni medyadaki kullanıcıya geçiş süreci, bizatihi sermayenin ötesinde Bourdieu sosyolojisinin, örneğin "habitus", "doxa", "ethos" gibi, diğer anahtar kavramlarını kaçınılmaz olarak çözümleme sürecine dâhil etmektedir. Bu doğrultuda, birbiri ile iç-içe geçen iki süreç üzerinden düşünülmesi anlamlı olacaktır. $\mathrm{Bu}$ süreçlerin ilki, yeni enformasyon ve iletişim teknolojilerinde kullanıcının bu kez üreten tüketici olarak konumlanmasıdır. Böylesi bir süreç metalaştırılanın aslında bizatihi "kullanıcı" olduğunu görünür kılmaktadır. Kitle medyasında üretilen metanın gerçekte emek gücü metası olarak izleyici olduğuna dair bir tartışmanın özellikle yeni enformasyon ve iletişim teknolojileri içerisinde yeniden ele alınması kaçınılmazdır. İkinci süreç ise, bu kez tam da Bourdieu sosyolojisi ile birlikte düşünme çağrısını daha da anlamlı kılmakta ve yeni enformasyon ve iletişim teknolojileri özelinde üretilen "değerin" nasıl tanımlanabileceğine dair özel bir tartışma çağrısı oluşturmaktadır. Gerçekten de, aslında hepsi de küresel medya şirketleri olan yapılanmalar için bu kez kullanıcının "aktif katılımı" üzerinden gelir elde etmek ve bir süreklilik oluşturabilmek oldukça anlaşılabilir bir durumdur. Ancak, burada tartışmayı daha da değerli kılabilecek unsurun internet kullanıcısının, söz konusu iki unsuru, hem üretici hem tüketici "olmayı"; neden, nasıl ve hangi değerler üzerinden gerçekleştirdiğidir. Bu soru, Bourdieu sosyolojisinin "alet çantasına" yeniden bakmayı gerekli kılar. Petri Hallikainen (2014:12-14); internet kullanıcısının özellikle "sosyal medya ağlarını" kullanmasının ve 
söz konusu kullanımın sürdürülmesinin bir değer üzerinden açıklanması gerektiğini belirtir. Ancak burada söz konusu değer; kullanıcının sosyal medya ağlarını kullanma gerekçesini oluşturan "psikolojik" kertede belirlenen değerdir. Özellikle sosyal medya ağlarını kullanım pratikleri söz konusu olduğunda, kullanıcıların "ihtiyaçları" ve sosyal medyaya atfettikleri "değerler" aslında, en azından bu çalışmanın yazarı tarafından öne sürüldüğü üzere, iki açıdan etkilidir. Gerçekten de bir yandan, kullanıcı için kullanımındaki sürekliliği sağlarken şirket için de sadık bir müşteri kitlesinin, farklı bir açıdan söylendiğinde Christian Fuchs'un yukarıda alıntılanan sözlerinde yer aldığı gibi, eş zamanlı bir "üreten tüketici" kimliğinin oluşmasını sağlamaktadır. Sosyal medya ağlarında üreten tüketicinin değerleri ve açıklaması aşağıdaki Tablo 1 içerisinde yer almaktadır.

Tablo 1: Sosyal Medya Ağlarında, Kullanıcının Değer Kategorileri (Sheth, Newman ve Gross; 1991:159-170’den aktaran Hallikainen, 2014:12).

\begin{tabular}{|l|l|}
\hline Kullanıcı için Değer Kategorisi & Değerin Tanımlanması \\
\hline İșlevsel Değer & $\begin{array}{l}\text { Kullanııının, sosyal medya ağlarını kullanma sürecinde amaçladığı ve } \\
\text { amacının gerçekleștiği değer. }\end{array}$ \\
\hline Sosyal Değer & $\begin{array}{l}\text { Sosyal medya ağlarının kullanılmasıyla, kullanııının amaçladığı sosyal } \\
\text { gruplarla bütünleșmesini içeren değer }\end{array}$ \\
\hline Duygusal Değer & $\begin{array}{l}\text { Sosyal medya ağlarının kullanılmasılla elde edilen duygusal tatmin ve bu } \\
\text { amaçla kullanımın sürdürülmesi. }\end{array}$ \\
\hline Bilișsel Değer & $\begin{array}{l}\text { Sosyal medya ağlarının kullanılmasıyla elde edilen bilgi, merakın giderilmesi, } \\
\text { yeniliğin sağlanması }\end{array}$ \\
\hline Koșulsal Değer & $\begin{array}{l}\text { Sosyal medya ağlarının kullanılmasıyla, kullanııının bir koșulu ya da durumu } \\
\text { yerine getirmesi (doğum günü için kutlama mesajları ya da yeni yıı mesajları } \\
\text { gibi). }\end{array}$ \\
\hline
\end{tabular}

Geleneksel medyadan farklı olarak, yeni enformasyon ağlarında bir yandan kullanıcının reklamcılara satılması süre giderken diğer yandan kullanıcının, değerlerinin metalaştırıldığı bir mübadele sürecine konu olduğu söylenmelidir. Böylesi bir eksen içinden bakıldığında, Hallikainen'in (2014:14) belirlediği gibi; kullanıcı değerinin; birincisi "güven" ikincisi "sosyal sermaye" olmak üzere, iki önemli tamamlayıcı ile birlikte oluştuğunu söyler. Bu yolla, hem kullanıcı için kullanma pratiğinin önemli bir sürekliliğe ulaşmakta hem de sosyal ödüllendirme sistemi üzerinden kullanıcının, yeni medya ağlarının kullanılması için önemli bir yer açılmaktadır. Maddi olmayan emeğe dair bir tartışmanın, kapitalizmin birikim yapısı içerisinde metalaştırma biçim ve yollarını önemli ölçüde genişleten böylesi bir kesit üzerinden düşünmemesi önemli bir açıktır. Çünkü Symthe'nin çalışmasına yöneltilen, meta biçiminin işlevini yanlış anlamak ve özgül meta biçimleri arasındaki ilişkiyi değerlendirememek ile böylesi bir emek sürecinin somut bir ücret iliş̧kisi oluşturmayacağı bu nedenle de izleyicinin kendi metasının mübadelesinde taraf olamayacağı ve yine böylesi bir emeğin kapitalistin denetiminde yeni metaları üretmek için kullanılamayacağı (Kıyan, 2015:47), yönündeki eleştirileri yeniden üretme "tehdidi" bulunmaktadır. Illetişim çalışmaları için böylesi bir tehdit, yeni enformasyon ve iletişim teknolojilerinin söz konusu ağlar üzerindeki denetimi nasıl gerçekleştirdiği bu yönüyle de ilkel birikim ve mülksüzleştirerek birikim tartışmasını 
gittikçe görünmez kılmaktadır. Örneğin Carolin Gerlitz ve Anne Helmond (2013:1348), Facebook'un kullanıcıları üzerindeki deneyiminin, 2010 yılı Nisan ayı içerisinde iki önemli araçla yeniden düzenlendiğini belirtir. Gerlitz ve Helmond'a göre, Facebook söz konusu tarihten itibaren "beğen" ve "paylaş" butonları üzerinden sosyal medya kullanımını önemli ölçüde dönüştürmüş ve araç temelinde merkezileștirmiştir. Gerlitz ve Helmond (2013:1351), Facebook örneğinde bașlattıkları tartışmalarını aslında bütün bir sosyal medya kullanım pratiklerine doğru genişletirken, bu teknolojileri içerisinde mübadele değerini oluşturanın artık kullanıcının "beğenisi" olduğunu söylemektedir. Araştırmacılara göre, sosyal medya ağlarındaki beğeniler aslında kullanıcıların bir yandan önemli bir bağlantı ekonomisi üzerinden benzer ya da farklı ağlara erişimini sağlarken bir yandan da şirketler tarafından sözü edilen bağlantıların sınıflandırıldığı, bir bakıma kullanıcının sosyal medya ile etkileşiminin ön tanımlı bir kullanım pratiğine doğru ilerlediğini belirtirler. Bununla birlikte, kültürel beğenilerin bir sınıf deneyimi içerisinde oluştuğunu belirlemek gerekir. Örneğin, Bourdieu sonrasında kültürel beğenilerin nasıl oluştuğunu yeniden tartışan Loic Wacquant'a (2014:205) göre; kültürel beğeniler, toplumsal analizin gerçek nesnesinin "sıradan ufkumuza üşüşen" birey ya da gruplar değil, maddi ve simgesel bağlardan oluşan ağların oluşturduğu örüntülerdir. Bu ilişki ağı içerisinde iki düzey ayırt edilmelidir. İlk düzey içerisinde, kişinin işgal ettiği ve dışsal biçimde algıyı ve eylemi kısıtlayan nesnel konumların kültürel beğeniyi olduğu kadar bir meta değeri tanımlanmaktadır. İkinci düzeyde ise yaşanan dünyayı içsel bir şekilde tecrübe edip etkin bir biçimde bireyin kurmasına vasıta olan (katman katman eklemlenmesiyle habitusu oluşturan) zihinsel algı ve değerlendirme şemaları bulunmaktadır (Wacquant; 2014:205). Yeni enformasyon ve iletişim teknolojileri içerisinde bir mübadele değeri üreten ya da metalaştırılan tam da böylesi bir ikinci eksendir. Ancak bu çalışmanın ilerleyen kısımlarında, sosyal medya ağlarının iki yeni düzey içerisinde ele alındığı söylenmelidir. İlk düzey, "işin bütün bir topluma yayılması" (Daubs, 2015:60) olarak tartışılmaktadır. İkinci düzeyi ise, kullanıcı emeğinin, geleneksel bir meta üretemediği tartışmasını izleyen "ücretsiz emek" (Fuchs, 2015:143) kavramsallaştırmasına yeniden dönmektir. Aslında böylesi bir tartışmanın temelleri bizatihi, toplumsal ilişkiler ağını da görünmez kılacak şekilde ilerleyen internet teknolojisi üzerinden atılmıştır.

Çalışma içerisindeki tartışmanın ikinci boyutu, yeni medya ortamlarında kullanıcı için habitusun nasıl belirlendiği üzerine gelişmektedir. Christian Fuchs (2014a:97), sosyal medya ağlarının, kapitalist toplumlarda değişen zaman rejiminin açık bir ifadesi olduğunu belirtir ve izleyici emeğinin daha geniş bir kapitalist sermaye birikim rejimi içerisinde ele alınması gerektiğini vurgular. İlerleyen kısımlardaki tartışmanın ve alan analizinin gerçekleştirilebilmesi adına Şekil 1 'in işlevsel bir bütünlük sunduğu belirtilmelidir. Çünkü yeni medya ortamlarının kullanıcı alanı, etkileşim, sosyal medya alanı ve mücadele olmak üzere dört eksenini birlikte düşünme sürecine çağırmaktadır. 
Șekil 1: Yeni Enformasyon ve Illetișim Teknolojilerinde Kullanıcı Emeği ve Dönüșümü (Wacquant; 2014:205 ve Hallikainen, 2014:14 tartıșmalarının değerlendirilmesiyle araștırmacı tarafından hazırlanmıștır).

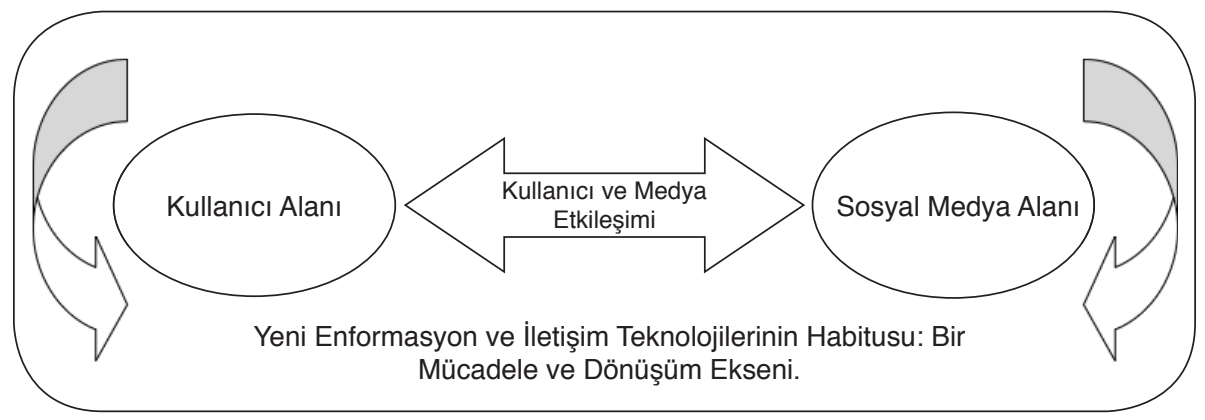

Şekil 1 içerisinde yer alan mücadele ve dönüşüm ekseni aslında maddi olmayan emeğin tüm kertelerinde ve üstelik kullanıcının henüz sürece katılımından daha önce belirlendiği alanı oluşturmaktadır. Christian Fuchs (2014a:97), sosyal medya ağlarının, kapitalist toplumlarda değişen zaman rejiminin açık bir ifadesi olduğunu belirtir ve izleyici emeğinin daha geniş bir kapitalist sermaye birikim rejimi içerisinde ele alınması gerektiğini vurgularken gerçekte tam da bu etkileşimi değerlendirmektedir. Ancak böylesi bir etkileşim, maddi olmayan emeğe dair çalışmaların en azından son döneminde kapitalizme dair anlamlı bir soruyu sormamaktadır.

\section{2. İletișim Çalıșmalarında İzleyici Emeği: Bedava Öğle Yemeğinden, Yemeği de Kendisi Yapan Kullanıcıya Doğru Bir Kavramsallaștırma}

Tarihsel bir sistem olarak kapitalizm, özellikle emek ve emeğin dönüşümünü amaçlayan bir tartışmanın odağında nasıl değerlendirilebilir? Gerçekten de bu soru özellikle yeni enformasyon ve iletişim teknolojileri söz konusu olduğunda, hem anlaşılabileceği hem de beklendiği üzere, kapitalizmin bütün bir tarihi boyunca kurduğu; "üretim güçleri" ve "üretim ilişkileri" arasındaki diyalektikten bağımsız olarak ele alınamaz. Ancak bu alt bölüm içerisinde yeni bir soruya daha intiyaç duyulmaktadır. Yeni enformasyon ve iletişim teknolojileri söz konusu olduğunda, "üretim güçleri" ve "üretim ilişkileri" arasındaki diyalektik nasıl çözümlenebilir ve yeni bir kesit nasıl açılabilir? Mike Wayne'in (2009:63), hem kapitalist sermaye birikim koşullarındaki değişimin hem de teknolojik güçlerin ve toplumsal ilişkilerin sürekli dönüşümüne yönelik bir üretim tarzının anlamlandırılabilmesi adına sorduğu soruyu yeniden ziyaret etmek gerekir. Soru; "ekonomik bir düzeyde yeni teknoloji paradigması, kapitalist iktisat döngüsünü aşmakta başarısız olmuşsa, yeni teknolojinin daha geniş bir toplumsal ve kültürel düzeyde getirdikleri nelerdir?" olarak belirlenmiştir ve bu kez sorgulama odağına toplumsal ve kültürel teknik üretim ilişkilerinin dâhil edilmesini içerecek denli yeni bir kesitin açılması gerekir. Gerçekten de "maddi olmayan emek" kavramsallaştırması, her ne kadar Marksist analizlerin değişen yorumları arasındaki anlamlı bir tartışmanın hatta çekişmenin odağını oluştursa da, bu çalışmanın çözümlemeyi amaçladığı üzere teknolojinin değişen değerler dizisi üzerinden yeni bir çerçevelemeye ihtiyaç duymaktadır. Bu alt bölüm içerisinde, daha önceki kısımda açıklandığı üzere, çalışmanın ilk eksenine dair bir tartışmanın bu yönüyle de özellikle iletişim çalışmaları 
özelinde sözü edilen "çerçevenin" geliştirilmesi amaçlanmıştır. Maddi olmayan emek, on dokuzuncu yüzyılda ilk kez Henry Storch tarafından (Özmakas, 2015:14) dile getirilmiş olmakla birlikte, kavramın güncel kullanımının genişlemesi ve bugün uzlaşı içerisinde işaret ettiği anlamın kurulabilmesi Otonom Marksist yaklaşım, özellikle 1960 ve 1970'li yıllar boyunca gelişen tartışmalarla birlikte atılmıştır. Utku Özmakas (2015:14), maddi olmayan emek kavramının geliștirilmesinde Maurizio Lazzorotto'nun önemli katkısını belirginleştirir. Lazarotto maddi olmayan emeğin, birbiriyle yakından ilgili iki özelliğini kavramsallaştırır. Birincisi, metanın enformasyon içeriğine dair yapmış olduğu gönderme olarak kavramsallaştırılmasıdır. Bu bağlamda, iş olarak tanımlanan emeğe dair bir çerçeve çizer. Örneğin dolaysız emek için gerekli olan becerilerin elde edilmesi ve burada maddi olmayan emek, yukarıda da tartışıldığı üzere üretim ilişkileri üzerinden ele alınır. Lazarotto'ya göre maddi olmayan emeğin ikinci kavramsallaştırma biçimi ise bu kez kültürel içeriğini üreten etkinlikleri odağına alarak normal koşullarda iş olarak kabul edilmeyen ancak bir dizi etkinliği içeren emeğin dönüşümüdür. Bununla birlikte, Lazarotto'yu da içeren ilk dönem maddi olmayan emeğe dair eksen sonraki dönemlerinde oldukça önemli bir dönüşümü, toplumsal dönüşümü, içerisine alarak değerlendirme eksenini oluşturur. İkinci dönemi, ağırlıklı olarak Hardt ve Negri'nin (2008:304'den aktaran Kıyan, 2015:43) tartışmasıyla birlikte başlatmak gerekir. Yazarlara göre; enformasyon ekonomisine geçiş sürecinin zorunlu olarak emeğin niteliği ve doğasındaki değişimi belirlemesi, maddi olmayan emeğin kavramsallaştırılması üzerine ikinci ekseni oluşturur. Hardt ve Negri'ye göre; enformasyon ekonomisinin bir bütün olarak, yukarıda ele alındığı üzere, kapitalizmin üretim ilişkilerini değiştirmesi sonucunda emeğin de gayri maddi bir nitelik kazanmasına yol açmakta bu açıdan bakıldığında ise önceki dönemlerden farklı olarak hem ürün hem de emek gayri maddileşmektedir. Bu doğrultuda maddi olmayan emek; "yani bir hizmet, bir kültürel ürün, bilgi ya da iletişim gibi maddi olmayan mallar üreten" bir dönüşüme tabii kılınmaktadır (Kıyan, 2015:43). Ancak bütün bu tartışmalar ekseni boyunca, kapitalizmin değişen birikim rejimlerine koşut olarak; dönüştürdüğü, yeniden inşa ettiği hatta kendi bağlamından kopartığı emeğin bu kez "gayri maddi” biçimlerine dair nasıl bir somutlukta ele alınabileceği gerçekte önemli bir ikileme de yol açmıştır. Olabildiğince genel bir düzeyde ele alındığında; izleyici ya da kullanıcı emeğinin, kapitalist üretim ilişkileri içerisinde zaten mübadele edilmek üzere üretilmemiş olmasının, bu kez kullanıcılar tarafından üretilmiş içeriği meta olarak değerlendiren çalışmalar için önemli bir yetersizliğe yol açtığını iddia eden görüş bu ikilemin ilk eksenini oluşturur (Toscano,2007:9). İlk eksen, bu nedenle herhangi bir mübadele ekseni oluşturmanın oldukça uzağında olarak değerlendirdiği maddi olmayan emek çalışmalarını da oldukça keskin bir eleştirinin odağına yerleştirmektedir. Buna göre; hem yanlış bir algının bu kez emek, değer, mübadele değeri, kâr, soyut emek ve emek sömürüsü gibi kapitalizmin içkin değerlerinin eleştirisini gerçekleştiremediği bu nedenle de içeriği boşaltılmış ve niteliksizleştirilmiş bir tartışma olarak değerlendirmektedir (Hesmondhalgh, 2010:272-277). İkilemin ikinci ekseninde ise, ilerleyen kısımlarda daha ayrıntılı olarak ele alınacağı üzere, Dallas Smythe'ın kitle iletişimin gerçek ürünü nedir? Sorusu üzerinden verdiği ve kitle iletişiminde metalaştırılanın aslında izleyicinin emeği olduğu yanıtının bu kez tek başına kapitalizmin yeni bir aşamasına geçişi değil böylesi bir aşamayla birlikte disiplin toplumundan kontrol toplumuna olmak üzere yeni bir toplumsal dönüşüme de (Harth ve Negri'den aktaran Özmakas, 2015:12) yol açtığı vurgusunu getiren ve bu kez maddi olmayan emek tartışmasını anlamlı bir bağlama yerleştiren yaklaşım bulunmaktadır. Yukarıda genel hatları üzerinden ele alınan ikilemin ikinci ekseni, özellikle Harth ve Negri'nin çalışmaları dikkate alındığında, 
maddi olmayan emeğin aslında tam da maddi bir meta değeri aldığını ve bu doğrultuda en az üç ana kertesinin ayırt edilebileceğini belirtir. Buna göre (1) maddi olmayan emek, enformatikleşmiş ve bizatihi üretim sürecini dönüştürecek bir biçimde iletişim teknolojilerini bünyesine katmış bir endüstriyel üretim süreci ile ilgilidir bu nedenle bizatihi meta ve üretim süreci ekseni dışında kavramsallaştırılamaz. (2) böylesi bir emek bir yandan yaratıcı ve zeka ürünü manipülasyon ve öte yandan da rutin simgesel manipülasyona ayrılmış analitik ve simgesel işlerdeki boyutları yeniden üretir. Son olarak (3) böylesi bir emek duyguların üretimi ve manipülasyonu ile ilgilenmekte olduğu için insani ilişkiler gerektirir bu yönüyle de başlı başına bir bedensel emek biçimi olarak görülmelidir (Hardt ve Negri, 2002:305-306'dan aktaran Özmakas, 2015:16). Silvia Federici (2014:118) tam da böylesi bir kesit içerisinden bakarak, maddi olmayan emeğin, emek ve sermaye ilişkileri bağlamında, çalışmanın özerk, öz örgütlenmeli ve üretken bir toplumsal işbirliğine dönüştüğü; nitelik bakımından yeni ve pozitif bir kurduğunu söyler. Buna göre, küresel kapitalizmin ihtiyaç duyduğu söz konusu maddi olmayan emek, tam da geleneksel olarak yapılan ayrımların (zihin emeği / kol emeği ya da kafa emeği / kol emeği gibi) ötesine geçerek tarihi boyunca işçiyi, zihin emeği sürecinin dışında tutan kapitalizmin son döneminde intiyaç duyduğu emek biçimini oluşturur. Bununla birlikte ikilemin her iki ekseni içerisinde de gerçekte önemli bir eksikliğin olduğu söylenmelidir. Brett Caraway (2011:694); tam da bu kesit içerisinde, iletişimin "çağdaş" bağlamının ve değişen dinamiklerinin son kertede bir bütün olarak izleyici emeğine dair bugüne değin kabul edilen bütün öngörülerin yeniden ele alınmasına doğru değișmesi gerektiğini belirtirken, böylesi bir düşüncenin sınıf yapısı ve kapitalist sistemin dönüşümü üzerine kurulması gerektiğini vurgulamaktadır. Ancak gündelik yaşam pratikler içerisinde, sınıf ve sınıfsal pratiklere dair ortak bir paydanın kurulmuş olması gerekir.

Christian Fuchs (2014a:99), böylesi bir ortak paydayı, çalışmanın henüz ilk kısımlarında ele alındığı üzere, Pierre Bourdieu'nün sosyolojisi üzerinden kurmaktadır. Ancak, özellikle kullanıcı emeği ve söz konusu emeğin dönüşümünü odağına alan bir yaklaşımın kurulabilmesi için, kapitalizm ve toplum arasındaki ilişkileri son kertede ekonomik, siyasal ve kültürel sermaye biçimleri ile bu sermaye süreçlerinin birikimi olarak ele almanın çok daha işlevsel olduğu belirtilmelidir. Buna göre, iktidarın üç biçimi ve toplumsal boyutları aşağıda tablo haline sunulmaktadır.

Tablo 2: İktidarın Üç Biçimi (Fuchs, 2014a:100).

\begin{tabular}{|l|l|l|}
\hline Toplumun Boyutları & İktidarın Tanımı & Modern Toplumlarda iktidarın Yapısı \\
\hline Ekonomi & $\begin{array}{l}\text { Üretilen, Tüketilen ve Dağııılan Kaynaklar ve } \\
\text { Kullanım Değeri Kontrolü }\end{array}$ & Para ve Sermayenin Kontrolü \\
\hline Siyasal & $\begin{array}{l}\text { Belirli toplumlarda ya da sosyal sistemlerde, } \\
\text { insanların yașamlarını belirleyen eksenler } \\
\text { üzerinde etki ya da kolektif karara ulașılması }\end{array}$ & $\begin{array}{l}\text { Hükümetin kontrolü, bürokratik devlet } \\
\text { kurumları, parlamento, askerlik, polis, } \\
\text { siyasal partiler, lobi grupları, sivil toplum } \\
\text { grupları vb }\end{array}$ \\
\hline Kültürel & $\begin{array}{l}\text { Ahlaki ilkelerin ve toplumda kabul edilen, } \\
\text { değerli, önemli olduğu düșünülen anlamların } \\
\text { belirlenmesi }\end{array}$ & $\begin{array}{l}\text { Toplumda, ahlaki ilkelerin ve anlamların } \\
\text { belirlendiği yapıların kontrol edilmesi } \\
\text { (üniversiteler, dini gruplar, aydın çevresi, } \\
\text { karar alma süreçlerini etkileyen gruplar } \\
\text { vb) }\end{array}$ \\
\hline
\end{tabular}


Christian Fuchs'un (2014a:103) iktidar biçimi olarak iletişim teknolojisi düşüncesi; emeğin kapitalist zaman rejimi içerisindeki dönüşümünü açıklarken aslında bir yandan da yeni enformasyon ve iletişim teknolojilerinin kapitalizmin birikim rejimi içerisindeki dönüşümünü açıklayabilme adına oldukça işlevseldir ve birbiri ile bağlantı içerisindeki altı ana kavramın varığını belirtir. Buna göre; kapitalizmin sermayenin yanı sıra, diğer alanlardaki birikim rejimini sürdürebilmesi için (a) teknolojinin, (b) sosyal değişimlerin, (c) yaşam temposunun modernleşme ile birlikte hızlanması gerektiğini ancak böylesi bir deneyimin gerçekleştirilebilmesi adına sürecin (d) ekonomik birikim, (f) işlevsel farklılaşma ve son olarak (g) kültürel mücadele tarafından yönlendirildiğini belirler. Funda Başaran (2005:32) tam da böylesi bir refakat içerisinde iletişimin eleştirel ekonomi politiğin anlamlı bir çerçeve sunduğunu belirtir. Çünkü yaklaşım bizatihi kapitalizmi kendi içerisindeki bütünlük üzerinden ele almaktadır. Christian Fuchs ve Vincent Mosco'nun (2014:35) değerlendirdiği gibi; "izleyicinin metalaşması ile başlayan ve internet üretkeminin artmasıyla yeni bir boyuta tırmanan üretken hale gelerek tüketme durumunun yükselişinin çözümlenmesi çabalarının" gerçekte bu çalışmanın hemen girişinde ele alındığı gibi kullanıcı emeğinin kapitalist bir mübadeleyi amaçlamasa dahi bir kapitalizmi kendi içerisinde temsil eden bir değere sahip olduğunu görünür kılmaktadır.

Meta pratik olarak paylaşımlar dikkate alındığında gerçekten de bu biçimde bir mübadele amaçlanmasa dahi, kullanıcı paylaşımlarının "kitle iletişimin gerçek üretimi nedir?" sorusu bağlamında bir değer oluşturduğu söylenmelidir. Ancak böylesi bir değerin hem görülmesi hem de çözümlenebilmesi bir dizi güçlükle örülüdür. Jernej Prodnik (2014:356); iletişim çalışmalarında izleyici emeğine dair ilginin aslında önemli bir ikilemle karşılaştığını ve bu nedenle "genelde "boş zaman" olarak görülen şeyin günümüzde özel türden bir emek olarak tanımlanabiliyor olmasını tahayyül etmek pek çokları için zor olabilir" demektedir. Çünkü yeni enformasyon teknolojilerinde düşünülmeyen bu araçların hem bir iletişim hem de bir üretim aracı olduğu gerçeğidir. Eran Fisher (2014:135-136), Marx'ın toplumun diyalektik olarak çözümlenmesi gerektiği konusundaki bütüncül yaklaşımını belirlerken, iletişim çalışmaları içerisinde Marksist medya çalışmalarının ya kültürel / ideoloji ya da siyasal iktisat olmak üzere iki eksenden birisini kullandığını bunun ise üretim ilişkilerinin ideolojik olarak nasıl desteklendiğini görünmez kıldığını belirler. Smythe'ın tezi, kitle iletişiminin izleyiciyi metalaştırırken bedava öğle yemeği sunduğu yönündeki eğretilemesi bu doğrultuda iyi bilinmektedir çünkü bir yandan izleyicinin kullanım değerini ve diğer yandan sınıf mücadelesini, "maharetle", gizlemektedir. Öte yandan böylesi bir yaklaşım aslında daha da önemli bir çelişkiyi, mülkiyet sahiplerinin ya da daha doğru bir ifade ile üretim alanındaki kapitalist müdahalenin sınırlarını belirlemekten uzaklaşmaktadır. Brice Nixon (2016:213), izleyici emeğini tartışmanın odağına alan araştırmaların, dijital medya şirketleri ve reklamcılar arasındaki ilişkisini önemli ölçüde çözümlediğini ancak böylesi bir tartışmanın şirketlerin gelir yaratma "yeteneğini" çözümleme gündemine almaktan önemli ölçüde uzaklaştığını belirler. Nixon; yeni enformasyon ve iletişim teknolojileri şirketlerinin de tıpkı geleneksel medya şirketlerinde olduğu gibi izleyici üyeleri ya da kültürel tüketiciler olarak kullanıcıları üzerinde mutlak bir denetimleri bulunmaktadır. Üretim alanında mülkiyet sahiplerinin aslında gittikçe de doğal karşılanan ölçüdeki müdahaleleri ve bu açıdan da emeğin dönüşümüne dair tartışmanın en azından somut bir örneğe yer vermesi gerekir. Burada tartışılacak örnek, aşında iletişim çalışmaları için de önemli bir değişime işaret etmektedir. O kadar ki, Dallas Smythe'nin erken dönemli izleyicinin metalaşması ve "bedava öğle yemeği" kavramsallaştırmasından 
gittikçe Antonio Negri'nin "emeğin ve iş süreçlerinin, fabrikalardan bütün bir topluma yayılması ve bu yayılmanın da makineler ekseninde gerçekleştirilmesi” düşüncesine diğer bir deyişle "toplumsal fabrika" tezine tam da söz konusu örnek üzerinden ulaşılabilmektedir (Daubs, 2015:60, Prodnik, 2014:352). Michael S. Daubs (2015:6263), 2011 yılı Kasım ayında küresel haber şirketi CNN Internenational'ın eski başkanı Jack Womack'ın, dijital yayıncılık olanaklarındaki gelişmenin ve kullanıcı tarafından üretilen yayın içeriklerinin ve bütün bunların yanı sıra sosyal medya ağlarının artık daha fazla istihdam olanağı sunmadığını bu nedenle şirket bünyesinden 50 çalışanın işten çıkartılacağı yönündeki açıklamasını yeniden değerlendirir. Asıında CNN International'ın şirket bünyesi içerisindeki değişim, yeni enformasyon ve iletişim teknolojileri ve emek arasındaki ilişkinin yeniden düşünülmesi için önemli bir kesit açmaktadır. Daubs (2015:60), yeni enformasyon ve iletişim teknolojilerini kullanıcı emeği bağlamında ele alırken tam da söz konusu medyanın yapısal koşullarının emek sürecini önemli ölçüde dönüştürdüğünü ifade eder. Ancak Smythe'ın çalışmasında bu gerçeklik ikincil kılınmıştır. Aksine, kapitalist yapı ve ilişkiler ağı içerisinde bedava bir ürün ya da hizmetin olamayacağını aksine izleyiciye ulaşan enformasyon, eğlence ya da eğitim materyallerinin aslında bir hediye, rüşvet ya da bedava öğle yemeği biçimlerinde ve var olan izleyiciler kadar, yeni izleyicilerin de sadakatini oluşturabilmeyi amaçladığını söyler (aktaran Caraway, 2011:699). Erdal Dağtaş ve Mehmet Emir Yıldız'ın (2015:140) belirlediği üzere; "izleyiciler hakkında elde edilen nitel ve nicel verilerin oldukça ayrıntılı bir hale gelmesi ise, medya şirketlerinin, izleyici metasından daha fazla artı değer üretmesi dolayısıyla, daha fazla sömürü anlamına gelmektedir". Aslında Christian Fuchs (2015:137), izleyicinin doğrudan bir meta olarak kabul edilemeyeceği yönündeki tartışmaya Marks'ın emek değer teorisi üzerinden bir yanıt üretirken tam da söz konusu tartışmalı alana iki önemli açıdan yeniden değer biçmektedir. Fuchs (2015:137), yeni enformasyon ve iletişim teknolojilerinin, bu açıdan özellikle Facebook ve Twitter'ın, kullanıcısı için yaşamsal bir araç sunmadığını ancak kullanıcının bu araçlar için değer ürettiğini belirler. Fuchs için, yeni enformasyon ve iletişim teknolojilerinde kullanılan zaman hiçbir biçimde klasik bir metanın (örneğin bir şişe coca colanın) tüketiminden oldukça farklıdır. Çünkü Fuchs'a göre (2015:137); "Facebook ve Twitter'da, tüketim süreci çevrimiçi iletişimi ve kullanım zamanını zorunlu kılar. Bütün bu zamanın hepsi sadece yeniden üretim zamanı değil (bir başka deyişle emek gücünün yeniden üretimi için zaman), aynı zamanda Facebook ve Twitter'ın reklam veren müşterilerine sunduğu veri metalarını üreten emek zamanıdır". Klasik bir metanın, tüketim pratiğinden farklı olarak yeni enformasyon ve iletişim teknolojilerini kullananlar söz konusu tüketim pratiği içerisinde emek zamanlarını yeniden üretmekle kalmaz böylesi bir zamanın üretim sürecinde yeni metaları da üretirler (Fuchs, 2015:138). Bu nedenle, her ne kadar sınırlı olarak tartışılsa da, iletişim çalışmaları için yeni enformasyon ve iletişim teknolojileri söz konusu olduğunda özel bir eksenin, yukarıda belirtildiği üzere ikinci eksenin, açıldığı belirtilmelidir. Böylesi bir ekseni yukarıda yer alan CNN'in "iReport" uygulaması özelinde değerlendirmek anlamlı olacaktır. Gerçekten de, gerek maddi ve gerekse maddi olmayan biçimlerinde ortaklaşa olarak yer aldığı için birlikte ele alınmasını da gerektiren bir unsur olarak, emeğin mülkiyet sahipleri tarafından ideolojik eksende bir denetime tabii tutulduğu ve yeni enformasyon, iletişim teknolojileriyle birlikte işin bütün bir toplumsal evrene, toplumsal fabrikaya, taşındığı artık oldukça açıktır. Ancak küresel bir medya şirketi olarak CNN'in bu kez yeni enformasyon ve iletişim teknolojileri üzerinden açtığı kesit aslında bu kez işin bütün olarak topluma yayıldığı ve bu kez "işin" anlamını değiştirmesinin ötesine geçen boyutlara da sahip olagelmiştir. Gerçekten de işin bu kez bütün bir toplumsal yaşama, gündelik yaşam 
pratiklerine doğru genişlemesi aslında, iletişimin politik ekonomisinin en azından eleştirel yorumlarında emek gücünün gittikçe belirsizleşmeye doğru ilerlemesi olarak değerlendirilse de (Caraway, 2011:702), aslında farklı bir tartışma dizgesine intiyaç duyulmaktadır. Medyanın mülkiyet yapısı ve mülkiyetin bu kez kullanıcı emeği üzerindeki kontrolü ile yeni enformasyon ve iletişim teknolojilerinin bizatihi, iletişimin değişen doğası ve anlamını etkileyebilme potansiyeli önemli bir sorgulama kaynağı olarak değerlendirilme eksenine alınmalıdır. Zafer Kıyan'ın (2015:52) işaret ettiği gibi, "kapitalizm kendisini sürekli farklı bir biçimde sunarken üretimden tüketime kadar olan süreçlerde farklılıklara yol açmaktadır". Ancak bu farklılıkları düşünmenin önemli bir yolu, Christian Fuchs'un (2014b:181) değerlendirmesinden yola çıkıldığında, Marksist eleştiriler içerisinde yer alan sınıf kavramına doğru genişleyen bir tartışmaya intiyaç duyar.

Fuchs (2014b: 181), kapitalizm ve üretici güçlerin gelişiminin ücretli olmayan işçilerin önemini arttırdığını ve ağırlıklı olarak bu nedenle de; "Marksçı sınıf analizi siyasal bir tasarı ise ve öyle kalmak istiyorsa, o zaman değişimin potansiyel faillerine ilişkin kavrayışını arılaştırması gerekir" değerlendirmesinde bulunur. Bununla birlikte, Marksist sınıf analizinin aslında böylesi bir "değişimin potansiyel faillerine ilişkin kavrayışını" yeniden canlandırabilecek önemli bir kesitin tam da yeni enformasyon ve iletişim teknolojileri üzerinden açıldığı söylenmelidir. Özellikle emeğin maddi üretim süreçlerinden giderek maddi olmayan biçimlerine doğru gelişen kavrayışın tam da yeni enformasyon ve iletişim teknolojilerinin etkisinden bağımsız ele alınamayacağı açıktır. Eran Fischer (2014:144-145), tartışmasında önemli ölçüde Facebook örneğini dikkate alır, geleneksel kitle medyasından sosyal paylaşım sitelerine doğru bir değişim izlendikçe hem izleyici emeğinin sömürülmesinin önünün açıldığını ancak izleyicinin yabancılaşmasının göreli olarak daha düşük olduğunu söyler. Marksçı sınıf analizlerine dair önemli bir değişimin aslında tam da böylesi bir izleyici emeğindeki, daha az yabancılaşma ancak daha çok sömürü, denklemin nasıl değişebildiğini tartışılması üzerinden açıldığı belirtilmelidir ${ }^{3}$. Ancak belki de böylesi bir tartışmanın yeniden kurulabilmesi için, tıpkı dünya ekonomisindeki 2008 krizinden bu yana sosyal bilimlerin diğer alanlarında olduğu gibi iletişim bilimlerinin de Marksist temelli yaklaşımları yeniden düşünmesi gerekir. Bu doğrultuda, McChesney (2007:55), internet çalışmalarının Marksist yorumlarının; 1. Kültür endüstrilerinde sermaye birikiminin eleştirisi. 2. Meta fetişizmi eleştirisi. 3. Egemen ideolojinin eleştirisi ve son olarak 4. Marks'ın da bir gazeteci olarak çalıştığı dikkate alındığında eleştirel ve bağımsız gazetecilik üzerinden egemen medya sisteminin eleştirisi olmak üzere en az dört önemli eksende yeni enformasyon ve iletişim teknolojilerinin yeniden düşünülmesine dair anlamlı araçları sunduğunu söyler. Bu doğrultuda, iletişim çalışmalarını aslında tıpkı "Rosetta taşının"4 gizemini çözebilmek yönünde önemli bir görev beklemektedir. Ancak iletişim çalışmalarını bekleyen söz konusu görev, özellikle izleyici emeği söz konusu olduğunda sanıldığından çok daha zorlayıcıdır. Çünkü Funda Başaran'ın (2014:12) değerlendirdiği gibi, maddi olmayan emek söz konusu olduğunda tıpkı coğrafi farklılıkların ülkelerdeki çalışmalar üzerindeki etkisi olmak üzere, önemli bir kısıt ve kesinti bulunmaktadır. 


\section{Mülkiyetin Kontrol Alanı Olarak Sosyal Paylașım Siteleri: Ekși Sözlük, Yapılanma ve Emek}

Bir sermaye birikim alanı olarak sosyal paylaşım sitelerinin; önemli bir ayırt edici niteliğinin emeği de, "toplumsal fabrikaya" eklemleyerek birikim alanını genișletmesi olduğu söylenebilir. Ancak böylesi bir genişlemenin, iletişimin politik ekonomisi içerisinde özel bir tartışma alanı oluşturmasına rağmen, önemli bir eksiğinin de olduğu söylenmelidir. Yeni enformasyon ve iletişim teknolojileri söz konusu olduğunda, mülkiyetin araç üzerindeki denetiminin nasıl gerçekleştiği daha açık söylendiğinde mülkiyetin bir disiplin ve kontrol aracı olarak bütün bir emek sürecini ve dönüşümü nasıl belirlediği anlamlı bir tartışmanın odağında yer almalıdır. Ekşi Sözlük örneği asılında site yazarlarının, site mülkiyeti için tam da böylesi bir denetimin önemli ancak eğlencenin bir sürekliliği içerisinde algılandığı için gizli bir örneğini oluşturur. Gerçekten de, kurulduğu 1999 yılından itibaren kurumsal kimliğini de emek üzerinden biçimlendiren Ekşi Sözlük için henüz kurulduğu ilk günden itibaren her adımının planlandığı bir örgütlenme ağı oldukça açık bir biçimde görülmektedir. Gerçekten de, Ekşi Sözlük sitesinin henüz ana sayfasında, kullanıcı bilgileri ve giriş kısmının altında yer verdiği "giremeyiş" bölümünde, sitenin kayıtlı kullanıcısı olabilmek için aslında esprili bir dilin örttüğü ve koşulları itibariyle oldukça ciddi ve keskin bir sözleşme beklemektedir.

Șekil 3: Ekși Sözlük Sitesi Giriș Ekranı (http://www.eksisozluk.com/giris)

\begin{tabular}{|c|c|c|c|c|}
\hline \multicolumn{2}{|l|}{ ekșisözlük } & başlk, \#entry ya da @yzzar & $-a$ & grilis kaytol \\
\hline popüler & \#ilighkiler & \#siyaset & & ¿ ekșișeyler \\
\hline popüler & & giriş & & \\
\hline gündem debe Th & & kullanıc bilgiteri & & \\
\hline $\begin{array}{l}\text { hamza hamzaos glu enteresan } \\
\text { sekilde isteklydi }\end{array}$ & & & & \\
\hline $\begin{array}{l}\text { cocuuklara tecavaz eden } \\
\text { eğitim-senli solcu ö̆rettmen }\end{array}$ & ${ }^{87}$ & sifire & & \\
\hline $\begin{array}{l}11 \text { nisan } 2016 \text { beşiktas } \\
\text { bursaspor maç' }\end{array}$ & 779 & U unutma bunları sorucam sonra & & \\
\hline $\begin{array}{l}11 \text { nisan } 2016 \text { pkk diyarbakir } \\
\text { hani saldiris! }\end{array}$ & ${ }^{147}$ & ran & & \\
\hline $\begin{array}{l}12 \text { nisan } 2016 \text { marmaray'in } \\
\text { raydan çlkması }\end{array}$ & 53 & $\begin{array}{l}\text { giremeyiş } \\
\text { sifremi nnuttum } \\
\text { kaytti kullancio olunası }\end{array}$ & & \\
\hline
\end{tabular}

Ekşi Sözlük giriş ekranındaki "esprili” dil, aslında bir bakıma sosyal paylaşım sitelerinin mülkiyetin denetimindeki ve oldukça "sıkı kontrollü" bir alan olduğunu önemli ölçüde gizlemektedir. Gerçekten de, giriş kısmının altında yer alan ve genellikle sitelerde kullanıcı adını ve parolasını kaydet kısmının bu kez "unutma bunları sorucam sonra" ifadesi ile değiştirilmesi, giriş kısmında kayıtlı olmayan kullanıcıların "giremeyiş" bağlantısı üzerinden siteye kayıt olmaları ve sözleşmede kullanılan dil gerçek bir kontrol alanı olarak sosyal paylaşım sitelerini gizlemektedir. Sosyal paylaşım sitelerinin, kullanıcısı için ön belirlenmiş bir alan oluşturması aslında iletişim çalışmalarının son dönem tartışmaları içerisinde özel bir yere sahiptir. Örneğin Alberto Romele ve Marta Severo (2016:9-10), Facebook ve Twitter örneğinde, beğeni ekonomisini ele alırken sosyal paylaşım sitelerinin karşılıklı değişim ekonomisi oluşturduğunu ve onların ifadesiyle "hediye ekonomisinin" aslında sosyal medya platformlarının tamamı için geçerli olduğunu belirtmektedir. Her ne kadar ilk bakışta; Romele ve Severo'nun hediye ekonomisi olarak değerlendirdiği sosyal paylaşım sitelerinin gündelik pratikleriyle bu 
çalışmanın odağındaki sitenin, kullanıcıları için hazırlamış olduğu ve ön belirlenmiş bir alanı hazırlayan unsur olarak sözleşmeler arasında doğrudan bir bağın kurulması güçtür. Ancak, aslında her iki formunda son kertede kullanıcının içerisinde üstelik aktif olarak yer aldığı habitusu oluşturan bir pratik olarak konumlandığı söylenmelidir. Kamusal iletişimin gerçekleştiği bir biçim olarak kullanıcı için ön belirlenmiş ve asında sıkı bir biçimde kontrol edilebilen bir alanın oluşturulabilmesinin yol ve yöntemlerinin farklılaştığı söylenmelidir. Yukarıda, şekil 2 içerisinde, tartışıldığı üzere site kullanıcılarının içerisinde yer aldığı ve Bourdieu'nün sosyolojisinden ödünç alınan terimle kullanıcının habitusunu belirleyen böylesi bir dizi yaklaşımın, aslında henüz başlangıcından itibaren izleyici emeğinin önemli ölçüde kullanıldığı ve üstelik böylesi bir düzenlemenin, tek taraflı ve şirketin çıkarlarını korumaya yöneldiği belirtilmelidir. Gerçekten de, Site ve kullanıcıları arasındaki 28 Şubat 2016 tarihindeki, medyanın egemen söylemlerinde "direniş" olarak değerlendirilen, kırılmanın hemen bir ay öncesinde, 26 Ocak 2016 tarihinde, değişen sözleşme; mülkiyetin çıkarları doğrultusunda kullanıcı emeğinin nasıl da dönüştürüldüğüne dair anlamlı bir dizi örneği sunmaktadır. Aşağıdaki tablo 3 içerisinde, kullanıcı emeğinin nasıl metalaştırıldığı ve dönüştürüldüğüne dair sözleşmenin ilgili maddeleri yer almaktadır.

Tablo 3: Ekși Sözlük Sitesinde, Kullanıcı Emeğinin Metalaștırılma Pratikleri (http://www.eksisozluk. com/eksi-sozluk-kullanıcı-sozlesmesi-2602660'den kullanıcının, site içerisinde nasıl konumlandığı ve metalaștırılmasına dair maddeler sınıflandırılarak alınmıștır).

\begin{tabular}{|c|c|}
\hline Ekși Sözlük Sitesinde Kullanıcı Sözleșmesi & Site ve Kullanıcının Yükümlülükleri \\
\hline Site'nin yasal olarak kendisini konumlaması & $\begin{array}{l}\text { Site, kendisini yalnızca "yer sağlayıcı" olarak göstermekte } \\
\text { ve içerikteki herhangi bir sorumluluğa yazarı ile birlikte } \\
\text { tabii tutulamamaktadır. Sözlük sözleșmesinin, } 26 \text { Ocak } 2016 \\
\text { tarihindeki değișiminden önce sahip olduğu ve yalnızca altı } \\
\text { maddeden olușan sözleșmesinin, "beta versiyonu” olarak } \\
\text { bilinmektedir, yeni sözleșmede hiçbir șekilde korunmadığı hatta } \\
\text { bu çalıșmanın yazııldığı dönemde erișime dahi kapalı olduğu } \\
\text { söylenmelidir. }\end{array}$ \\
\hline
\end{tabular}


Sözleșme içerisinde, kullanıcı emeğinin metalaștırıımasına dair ilkeler
Yeni sözleșmenin, 26 Ocak 2016 tarihinde yürürlüğe girmesi ile birlikte oldukça anlamlı değișimlerin tam da bu alanda yașandığı belirtilmelidir. Burada söz konusu olan, yalnızca kullanıcının yasal olarak 18 yașında olması değil bununla birlikte ve çok daha belirgin olarak kullanıcı karșısında, site yöneticilerine özel bir alan sağlayan maddeler bulunmaktadır. 0 kadar ki, "gerekli görülen takdirde" ve "hiçbir gerekçe gösterilmeksizin" içeriğin kısmen veya tamamen yayından kaldırılması, kullanıcı sözleșmesinin feshedilebilmesi, yazarlığın iptal edilebilmesi böylesi ağır sonuçları olan maddelerden birisidir. Bunun gibi, kullanııının yazarlık kaydını gerçekleștirmesi durumunda, site yönetiminin haberli veya haber vermeksizin ișlenebilmesi, saklanabilmesi ve en önemlisi yazarların veri girișlerinin izin alınmaksızın kullanılabilmesi site yönetiminin, kullanıcı emeğinin metalaștırılabilmesine dair oldukça güçlü maddeleri olușturmaktadır. Ancak bu doğrultuda oldukça önemli bir madde, telif hakları ile ilgili düzenlemeler arasında yer almaktadır. Maddeye göre; yazarlar tarafından olușturulan tüm içerikler, Ekși Sözlükte yayında olduğu süre içerisinde ekși teknolojinin söz konusu içerikleri bașta ekiș șeylerde olmak üzere, uygun gördüğï bütün ortamlarda kendi kullanımında olan markalar altında ve / veya diğer internet sitelerinde ticari amaçla kullanma hakkına sahip olacaktır. Bu madde özellikle kullanıcı emeğinin metalaștırılma pratiğine ilișkin anlamlı bir örneği olușturmaktadır. Üstelik böylesi bir süreç içerisinde kullanıcıya herhangi bir telif ödenmediği gibi kullanıcının böylesi bir düzenlemeden korunabilmesi ancak kullanıcı hesabının kapatılması ile mümkün hale getirilmiștir. Bununla birlikte, yazarların verilerinin, internet dıșındaki ortamlarda kullanılması ve bundan kâr elde edilmesi halinde Sözlük yönetiminin takdir edeceği miktarda telif ödemesi yapması taahhüt edilmiștir.

Sözleșmede, kullanıcı tarafından üretilen içeriğin kullanılmasına dair ilkeler
Sözleșme içerisinde yer alan bir diğer madde; "bu sözleșme ekși teknoloji tarafından önceden duyurulmaksızın ve tek taraflı olarak değiștirilebilir. Değișiklik sonrası sitenin kayıttı kullanıcı olarak kullanım sözleșme değișikliklerinin kabulü anlamına geleceğinden, sözleșme metnini belirli aralıklarla kontrol etmenizi tavsiye ederiz" ilkesi getirilmiștir. Bu bağlamda sitenin kullanım sözleșmesindeki değișikliklerin takibini yine kullanıcıya yüklemesi ve daha önemlisi sözleșmenin kullanıcılarına duyurulmaksızın tek taraflı olarak fesih ve yeniden düzenlenebilmesi duyurulmaktadır . 
Sözleșmede, bağlantı ekonomisinin kullanılması ve söylemler arası yapılanma
Ekși Sözlük Yönetiminin bu doğrultuda, yukarıda da alıntılandığı gibi, kullanıcıların ürünlerini yine tek taraflı ve kendi takdir edeceği ticari ortamlarda kullanma hakkına da sözleșme eliyle sahip olmaktadır.

Ekşi Sözlük isimli sitenin kullanıcı emeğini bu denli metalaştırma pratiği aslında nerede ise yeni enformasyon ve iletişim teknolojileri ile birleşen "yeni medya sektörünün" ortak bir niteliğini oluşturmaktadır. Robert Perry'nin (2014:293) işaret ettiği gibi enformasyonel kapitalizm içerisinde egemen yapı ve pratiklerin eleştirisinde halen Marx'ın sömürü kuramının geçerli olduğu görülmektedir. Çünkü bilgi ortak ve toplumsal bir süreçtir ama bilgiye sermaye tarafından el konulmakta ve bu el koymayla birlikte, bilgi üreticileri sömürülen bir sınıf haline gelmektedir (Fuchs ve Zimmerman, 2009:95'den aktaran Prey, 2014:285). Yeni ağ mimarisi ve ekonomisi içerisinde, tıpkı mülksüzleştirerek ya da zapt ederek birikim sürecinde olduğu gibi, dışlama ve sömürü arasında yakın bir ilişki bulunmaktadır. Gerçekten de, Manuel Castells'in (2013:20) çalışmalarında somutlanan "ağ kuramı" yaklaşımı ve ağ mimarisi bizatihi Castells tarafından şöyle açıklanır: "iktidar ilişkilerinin toplumu oluşturduğu, çünkü iktidar sahiplerinin kendi değer ve çıkarlarına göre toplumsal kurumları inşa ettiği öncülünden yola çıkıyorum. İktidar zorlama yoluyla (meşru olsun olmasın, devletin kontrolü altındaki şiddet tekeliyle) ve / veya sembolik manüpülasyon mekanizmaları yoluyla insanların zihinlerinde anlamlar yaratılmasıyla icra edilir”. İktidar oluşturmanın böylesi bir biçimi, Perry (2014:294) tarafından kaçınılmaz olarak Foucault'un iktidar kuramına bağlanmaktadır ancak ağın oluşturduğu iktidar, hangi biçiminde olursa olsun, kaçınılmaz olarak bir içerme ve dışlama mekanizmasını görünür kılmaktadır. Ekşi Sözlük ve diğer sosyal paylaşım sitelerinin kullanıcı emeği üzerinden somut bir maddi karşılığa ulaşabilmesi aslında, sözleşmede de görüldüğü gibi, hem bir içerme hem de bir dışlama mekanizması olmasının yanı sıra bir sömürü ilişkisidir. Ancak site yönetimi örneğinde görüldüğü üzere süre giden sömürünün gittikçe bir kırılmaya doğru yön değiştirdiği görülmektedir. Bu aslında, emeğin kültürel bir iş olarak görüldüğüne dair işaretlerde okunmalıdır.

\section{Emek ve Bir Mücadele Alanı Olarak Kültürel İș}

Ekşi Sözlük sitesi kullanıcıları için, emeğin giderek bir kültürel iş olarak değerlendirilmesinin sözleşme değişimi ile başladığı ve site tasarımının da değişmesinin ardından bir kırılma eksenine doğru değiştiği görülür. Gerçekten de sitenin eski tasarımının aksine bu kez link verilen reklamların, kullanıcıları tarafından devre dışı bırakılamaması üzerine, 28 Şubat 2016'da bu kez site yazarlarının o güne değin girdikleri "entry" lerin silinmesi ile başlamıştır. Site kullanıcıları ve yöneticileri arasında neredeyse bir kırılma olduğu söylenmesi gereken 28 Şubat sonrası yapılanma, asında belirli aralıklarla daha önce de gerçekleşmiş olan site tasarımının bu kez diğer düzenlemelerin aksine reklamsız bir sayfa görünümüne izin verilmemesi ile site kullanıcılarının kullanımını zorlaştıran bir dizi değişime dayanmaktadır. Bununla birlikte oldukça önemli bir diğer unsurun gerçekte tam da sosyal paylaşım ağlarında maddi olmayan emeğin ve söz konusu emeğin dönüşümünün yeniden düşünülmesi adına önem taşıdığı belirtilmelidir. Gerçekten de Site Yönetiminin, sözleşmenin ele alındığı kısımda belirtildiği gibi, site yazarlarının ticari getirisinin yüksek olduğu da söylenebilecek olan mesajlarını izin almaksızın "ekşi teknoloji” isimli bir diğer sitesinde kullanacak olması bu doğrultuda önemli bir kırılmadır. Yönetimin, yazarları ile başlamış 
olan kırılmayı daha da derinleştiren bu uygulaması diğer yandan maddi olmayan emek ve birikim rejimi ilişkisine, Marx'ın ilkel birikim kuramı üzerinden, bakılmasını gerekli kılmıştır.

Mattias Ekman (2014:88-89); Marx'ın Kapital'deki tartışmasını yeniden hatırlatır ve ilkel birikimin, kapitalizm öncesi üretim biçimlerinin kapitalizme dönüştürüldüğü süreci açıkladığını belirtir. Üreticilerin, üretim araçlarından kopartıldığı, bir bakıma üretimin hem tarihsizleştirildiği hem de mekânsızlaştırıldığı süreci işaret etmektedir, bu şekilde de piyasada satılan ücretli emekçilere dönüştürüldüğü böylelikle aslında emek gücünün de metalaştırıldığı bir süreci ilkel birikim kuramı açıklamaktadır. Her ne kadar Ekşi Sözlük yönetiminin, site yazarlarının emeklerini maddi üretim süreçlerine dönüştürmesiyle ilkel birikim kuramı ilk bakışta kolay anlaşılabilecek bir bütünlük sunmasa da aslında sanıldığının aksine tam da böylesi bir sürecin kurulduğu söylenmelidir. Gerçekten de Eran Fisher'in (2014:123), yine Marx'ın tartışmasından yola çıkarak değerlendirdiği gibi, üretim ilişkilerine bütünüyle yayılmış olan zamanın ve sömürünün aldığı biçimler aslında medyanın tam da maddi olmayan emekle kurduğu sömürü ilişkisine de yayılmaktadır. Eran Fisher'e (2014:123-124) göre, sermayenin yeniden üretim sürecine aktarabilmek için kullandığı artı değeri arttırabilmek aslında son kertede emeğin sömürülmesi üzerine temellenmektedir. Bu doğrultuda iki sömürü biçimi ayırt edilir ki, genişıtetilmiş sömürü çalışmaya ayrılmış zamanın arttırılmasına ilişkin teknik ve düzenlemelere işaret etmekteyken medya özellikle yeni enformasyon ve iletişim teknolojileri ikinci sömürü biçimini yani derinleştirilmiş sömürüyü kullanır. Bu doğrultuda derinleştirilmiş sömürü; çalışmanın ritmini hızlandırarak ya da iş sürecini daha verimli kılarak, işçilerin daha az zamanda daha fazla üretmesini sağlayarak gerçekleşmektedir. Daha önce de tartışıldığı üzere, yeni enformasyon ve iletişim teknolojilerinin belki de geleneksel medyaya göre oldukça özgün yanını; ekonomikkültürel ve siyasal olmak üzere üç önemli gücün tam da birikim için hızlandırılması oluşturmaktadır. Yeni enformasyon ve iletişim teknolojilerinin, kapitalizmin hızlandırılmasına dair özel bir uğrak olarak ele alınması tam da yeni birikim düzeni içerisinde teknolojinin nasıl konumlandığını çözümleyebilmeye dair örnekleri birbiri ardına sunmaktadır. Yeni enformasyon ve iletişim teknolojileri ile sermayenin iletişimini, hız üzerinden, tartışan Vincent R. Manzorella ve Atle Mikkola Kjosen (2014:222), eleştirel iletişim çalışmalarına dair bir eleştiriyi de çizerek hız ve birikim arasındaki ilişkiyi, "Marksist medya çalışmalarına üretim merkezli çözümlemeler ya da altyapıüstyapı çözümlemeleri hâkimdir" olarak değerlendirir. Ancak Christian Fuchs gibi istisnai birkaç düşünürün aslında yeniden Marks'ın metanın başkalaşım çevriminin ve sermaye birikiminin mantığını bir başlangıç olarak ele alabildiğini belirtirler (Manzorella ve Kjosen, 2014:222). Böylesi bir yaklaşımın aslında kapitalizmi hem metaların hem de ideolojilerin üretim, dolaşım ve tüketim sistemi olarak ele alabilmesinin önünü açtığını belirtirler. Böylesi bir değerlendirmenin ardından, kapitalizm ve sermayenin hızlanma mantığını modern toplumlar içerisinde değerlendiren Christian Fuchs'un tartışmasına dönmek gerekir. Bu tartışmanın ardından, Ekşi Sözlük örneği üzerinden sermaye birikiminin, emeği dönüştürerek, hız ile kurduğu diyalektik değerlendirilecektir. 
Șekil 4: Modern Toplumların, Ekonomik-Kültürel ve Siyasal Sistemlerinde Hızlanma ve Birikimin Doğası (Fuchs, 2014:105).

Ekonomik Birikimin Mantığı-“Zaman, paradı»”

Ekonomi Hızlanması

Daha kısa zamanda daha fazla üretim, dolaşım ve tüketimin metalaştırılması

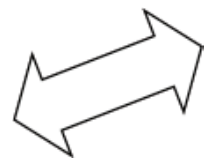

Dasha kısa zamanda, üretim ve yönetimin uzmanlaşması

Kültürün Hızlanması: Kültürel Güç

Kültürel birikimin mantığı -

"Yaşam / Zaman kısadır".

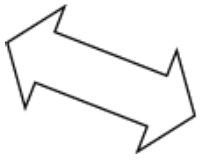

Daha kısa zamanda, daha fazla karar ve Uzmanlaşması sosyal ilişkinin üretilmesi, yönetilmesi

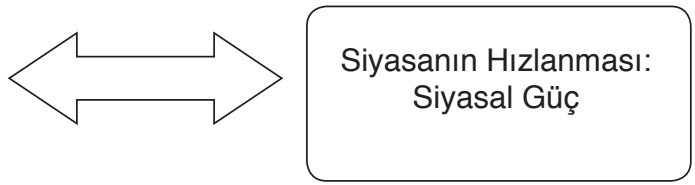

Siyasal birikimin mantığı -

"Zaman güçlü ve İktidarlıdır".

Christian Fuchs'un (2014:105) yukarıdaki şekil 4 içerisinde özetlenen modern toplumlarda, zaman, kültür ve siyasa olmak üzere, üç üretici gücün arasındaki ilişkinin değerlendirilmesi gerçekte en azından önemli ölçüde kapitalizmin sermaye birikim mantığının tartışılabilmesine olanak sunmaktadır. Buradan yola çıkarak, Ekşi Sözlük yönetiminin bir yandan sözleşmeyi değiştirirken diğer yandan kullanıcıları ile gerçekleştirdiği yeni sözleşmede bu kez, ticari başarısı olduğu da düşünülen, kullanıcı mesajlarının Ekşi Teknoloji olarak isimlendirilen yeni bir platforma aktarılarak metalaştırılması, sermaye birikim mantığı içerisinde ele alınmalıdır. Gerçekten de Manzorelle ve Kjosen'in (2014:235); “üretim alanında her daim kullanılmamış kapasite vardır ki bu Marx'ın göreli artı-değer kavramıyla işaret ettiği şeyin bir parçasıdır. Dolaşım zamanını kısaltan ya da diğer engelleri etkin biçimde aşan medya, sermayenin üretici potansiyelini serbest bırakır. Üretim alanında serbest bırakılan zaman, artı-emek zamanına dönüştürülebilir" olarak açıkladıkları zaman ve sermaye iletişimi tam da Ekşi Sözlük yönetiminin yeni uygulamasını anlamlandırmaktadır. Yukarıdaki yer aldığı üzere, bir üretim aracı olarak yeni medya gerçeği bu kez Ekşi Sözlük yönetiminin tam da emeğin ürününe el koymasıyla belirlenmektedir.

Üretim zamanında, o güne değin atıl olarak duran artı üretimin metalaştırılması, Ekşi Teknolojiye aktarılması, bu şekilde yeni bir platform için artı üretim yapılması üzerinden değil aksine var olanın yeniden metalaştırılması üzerinden bir emek biçimini serbest bırakırken asıında artı emek zamanına dönüştürmektedir. Ekşi Sözlüğün bir dizi süreç ve yöntem üzerinden metalaştırdığı emeğin, 28 Şubat 2016 tarihinde büyük bir eyleme 
dönüşerek protesto edilmesi bir diğer sürecin enformasyonel kapitalizm döneminde emek cephesinin de yeniden değerlendirilmesi için de yeni bir olanak sağlamaktadır. Mülkiyetin maddi olmayan emek üzerinden yeni bir birikim oluşturmasına dair iletişim çalışmalarının açtığı tartışma alanı aslında ekonomik olduğu kadar politik olanla da yeniden bir bağ kurmak zorundadır. Nicole S. Cohen (2014:58); "emek süreci, "yönetsel hakimiyet için devam eden bir iktidar mücadelesi" yüzünden değil, ama "sömürünün ve artı değer üretiminin (...) ana dinamiğinin alanı olduğu için politiktir" ifadesini kullanır. Ancak, gerçekte izleyici emeği üzerine temellenen bütün bir tartışma dizgesinin ekonomik ekseni politik olana bağlarken, tıpkı Cohen'in (de) yaptığı gibi, önemli bir eksiğe sahip olduğunun da söylenmesi gerekir. Karin Fast, Henrik Örnebring ve Michael Karlsson (2016:2) tam da bu eksiği vurgularlar. Gerçekten de, yazarların belirlediği gibi Marx'ın emek analizi içerisinde emeğin bir değişim değeri ve bir de kullanım değeri bulunmaktadır ve bu yönüyle "serbest" emek tartışması asında somut bir bağlam sunamaz. Yeni enformasyon ve iletişim teknolojileri söz konusu olduğunda aslında yeni bir "kör noktadan" bahsetmek bu nedenle anlamlı olacaktır.

\section{Yeni Kapitalizm ve Emek: Kültürel İș Olarak Kullanıcı Emeği}

Yeni kapitalizm ve izleyici emeği arasındaki bağı değerlendiren yaklaşımlara göre, yukarıda tartışıldığı üzere, emeğin toplumsal bir fabrikaya dönüşerek bütün bir topluma yayılmasının ya da "serbest" emek üzerinden değerlendirilmesinin anlamlı ancak eksik olduğu söylenmelidir. Karin Fast, Henrik Örnebring ve Michael Karlsson (2016:23), aslında bütün bir iletişim çalışmalarına egemen olan söz konusu eksiği işaret etmektedirler. Onlara göre serbest emek üzerine temellenen çalışmalar aslında iki önemli probleme, üstelik eş zamanlı olarak sahiptirler. Illk problem, emek ve dönüşümü üzerine çalışan araştırmacıların, çalıştıkları bağlamı dikkate almaksızın ve fark gözetmeksizin "serbest emek" kavramını kullanmalarıdır. Oysa Fast ve arkadaşlarının belirlediği gibi yeni enformasyon ve iletişim teknolojileri söz konusu olduğunda önemli bir dizi farkın vurgulanması ve çalışılan aracın sunduğu bağlamın değerlendirilmesi gerekir. Çünkü bu araçlarda emeğin her zaman, bilgisayar oyunlarında olduğunun aksine, gönüllü ve haz arayışı peşindeki kullanıcının emeği üzerinden şekillenmediği bilinmektedir. Öte yandan kullanıcının özerkliğine dair vurgunun da tüm koşullarda aynı olduğunu söyleyebilmek mümkün değildir. Aksine izlenen, denetlenen ve kontrole açık bir emek deneyiminin kurulduğunu da söylemek gerekir. Fast ve arkadaşlarının, emeğe dair çalışmalara getirdikleri ikinci eleştirisi, serbest emek düşüncesini ilerleten çalışmaların, böylesi bir emek sürecini daima yeni bir süreç olarak ve yalnızca dijital ağın ortaya çıkarttığı bir ekonomi içerisinde değerlendirmesi olmuştur. Oysaki yeni enformasyon ve iletişim ağları içerisinde, "serbest emek" gittikçe daha görünür olsa da, kavramın bizatihi hem bir tarihi bulunmakta hem de medyanın geleneksel biçimlerinin dahi böylesi, maddi olmayan, emeği sermaye birikimi içerisinde değerlendirdiği bilinmektedir.

Ekşi Sözlük örneğinden bakıldığında kullanıcı sözleşmesinin yanı sıra hatta daha da belirgin olarak bir anonimleştirme, kimliksizleştirme çabasına ve bunun yanı sıra kullanıcılıktan yazarlığa doğru uzanan sürecin nasıl kurulduğuna ve sonrasına işaret etmek gerekmektedir. 1999 yılında Sedat Kapanoğlu tarafından "sour times" sitesinin bir parçası olarak bu kez "kutsal bilgi kaynağı" söylemi ile kurulan Ekşi Sözlük (http:// www.tr.wikipedia.org), Türkiye'nin ilk sosyal paylaşım siteleri arasında yer almasının yanı sıra kullanıcı emeğinin denetimi üzerine de özel bir dikkat çekmektedir. Gerçekten 
de gerek Rong Zheng, Jiexun Li, Hsinchun Chen ve Zan Huang (2006:379) ve gerekse Burak Doğu, Zehra Ziraman ve D. Emrah Ziraman (2016: 7-8), metinlerin yazarlarla birlikte tanınmasına dair geleneğin özellikle 18. yüzyıl ve modernleşme ile başladığını belirtirler. Yazarının geliştirdiği bir metin olarak yazının tanınması daha çok böylesi bir geleneğin inşa ettiği bir pratiktir ve pozitivizmin etkisini taşımaktadır. Ancak, yeni enformasyon teknolojilerinin gelișmesi, özellikle Web 1.0'dan "etkileșim" ve "katılım" söylemleriyle inşa edilen Web 2.0 teknolojisine geçiş süreci, bu kez okurun rolüne ve metinle kurduğu etkileşime dair yeni bir kesitin açılmasına yol açar. Teknolojinin kullanıcısının, yazar ve okur olarak, bu kez metnin ve anlamın inşasında en az yazar kadar aktif olduğu yorumlanır. Ancak maddi olmayan emek özelinde düşünüldüğünde, özellikle de ilkel birikim ve kültürel üretimi gerçekleştiren yazarın mülkiyetinin zapt edilmesi kesitleriyle birlikte ele alındığında, etkileşim ve katılım gibi gerçekte hem niteliği hem de içeriğinin tanımlanmasının güç olduğu değerlerin yerine getirilmesinden daha keskin tanımlanması gereken boyutlarının olduğu işaret edilmelidir. Gerçekten de, kullanıcının kendi ismi ya da belirlediği herhangi bir isim ile bir paylaşım gerçekleştirmesinin, yukarıda tanımlanan etkileşim ve katılım süreçlerine nasıl bir engel oluşturabileceği oldukça tartışmalı bir süreci görünür kılmaktadır. Öte yandan özellikle Ekşi Sözlük yönetimi tarafından, hemen alt kısımda tanımlandığı gibi, yazarları arasında gerçekleştirdiği hiyerarşinin varlığı dikkate alındığında böylesi bir yöntemin yazarı "anonim kılma" yönünde kültürel metalaştırma sürecinde yalıtılması ve aslında emeğinin bu kez bizatihi Site tarafından zapt edilmesi anlamını içermektedir. Gerçekten de, Site tarafından yazarları arasında resmi olmasa dahi bir sınıflandırmanın yapıldığı ve bu sözü edilen sınıflandırmanın, yazarların site üzerindeki etkinliklerini önemli ölçüde belirlediği söylenmelidir. Sosyal paylaşım sitelerinde maddi olmayan emeğin son kertede belirlenmiş bir statü üzerinden üretim sürecinde yer almasına ilişkin bir dizi örnek verilebilmesi mümkündür ancak Ekşi Sözlük sitesinin bu bağlamda oldukça kesin bir sınıflandırmayı tercih ettiği belirtilmelidir. Örneğin, Sözleşmede de belirtildiği gibi yazar girişlerinin öncelikli olarak kontrol edilmesi ve ancak uygun olan içeriklerin sitede yer alabilmesi denetimin ilk evresini oluşturmaktadır. Böylesi bir düzenlemenin uygulandığı diğer siteler kadar ancak şikâyet üzerine harekete geçen ve içeriğin yasal bir zorunluluk olarak kaldırıldığı sitelerin varlığı bilinmektedir. Ekşi Sözlük sitesinin bu doğrultudaki ikinci kontrolü, Wikipedia'da yazıldığı gibi (http:// www.tr.wikipedia.org, 2016:1), yazar içeriklerinin "moderatör" ve "gammaz" adı verilen gönüllü üyeler eliyle kontrol edilmesi ve onların işbirliği ile siteden uygun olmayan içeriklerin kaldırılabilmesidir. Ancak böylesi bir denetim aslında örgütlü bir üretim alanındaki "ustabaşı" denetimi ile örneklendirilebilir. Böylesi bir denetimin ikinci boyutu ise, sitenin önemli ölçüde eleştiri almış olan yeniden yapılanması ile ilgilidir.

Șekil 5: Ekși Sözlük Sitesi'nde Maddi Olmayan Emeğin Denetimi (http://www.eksisozluk.com).

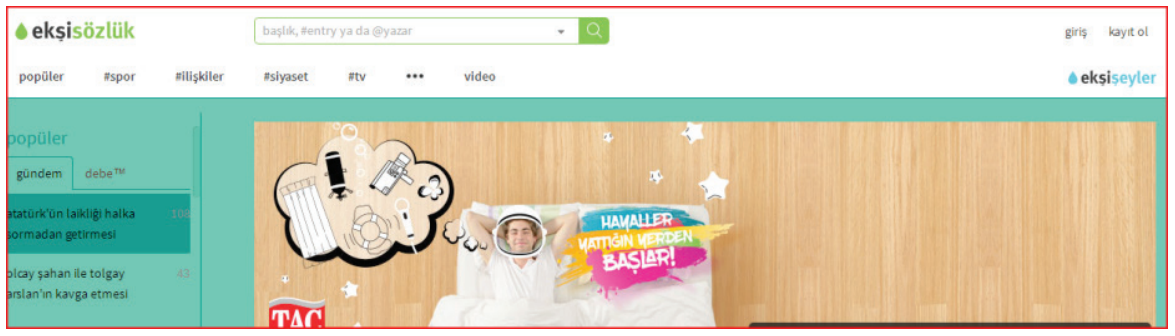


Sitenin ana sayfasında, ekşi sözlük ibaresinin hemen altında başlayan tuşlar, yazarlardan gelen içeriklerin "popüler", "spor", "ilişkiler", "siyaset", "tv" ve son olarak "video" altında sınıflandırılmasını sağlarken, popüler tuşunun tıklanması ile "gündem" ve "debe-dünün en beğenilen entry'leri" üzerinden yeni bir sınıflandırma sürecinin kullanıldığını göstermektedir. Sosyal paylaşım sitesinde, yaptığı üretim üzerinden herhangi bir bedel almayan kullanıcının mesajının "en beğenilen" satırı altında değerlendirilmesi aslında bir bakıma hem üretimin sürekliliğini hem de bu kez beğeni üzerinden üretimin karşılığının alınması olarak değerlendirilebilir. Sitenin yazarları denetlemesine dair bir diğer yöntem ise, yazarların sitenin alım dönemlerine göre sınıflandırılması olmuştur. Belirli yıllara göre yazarlara verilen statüler şöyle tablo haline getirilebilir. Ekşi Sözlük sitesinin, 2005 yılından itibaren uyguladığı ancak beş yıl sonra uygulamadan kaldırdığı yazar statüsü ve sınıflandırılması (site içerisinde hiyerarşi olarak isimlendirilir) özel bir dikkat çekmektedir. Aşağıda tablo 4 içerisinde 2005 ve 2010 yılları arasındaki yazar sınıflandırması, nesil hiyerarşisi, yer almaktadır. Tablo 4 : Ekşi Sözlük Sitesi'nde yıllara göre alınan yazarlar ve statüleri (http://www. tr.wikipedia.org'dan alınan bilgilere göre hazırlanmıştır).

\begin{tabular}{|c|c|}
\hline Yillar & Yazarların Nitelikleri \\
\hline 2004 & $\begin{array}{l}\text { Bu tarihte alınan yazarların yanı sıra kayıtlı okuyuculara da diğer yazarların mesajlarının oylanmas } \\
\text { hakkı getirilmiștir. Bu tarihte yeni bir statü olarak } 1000 \text { adet mesaja ulașan yazarlara azimli } \\
\text { yazar statüsü tanınmıștır. Bu tarihin ardından kayıtlı yazarların aldıkları oylar (karma olarak } \\
\text { isimlendirilir) diğer yazarlar tarafından da görülebilmekte ve bu șekilde yazarlar arasında aslında } \\
\text { bir rekabet olușturulmaktadır. }\end{array}$ \\
\hline $2005-2008$ & $\begin{array}{l}\text { Bu yılda, yazar sayısının oldukça fazla olması nedeniyle bu kez yazar yerine kayıtlı okur sayısının } \\
\text { yükseltilmesi amaçlanmıștır. Ancak } 2005 \text { Aralık ayında yeni yazarlar (yedinci nesil) siteye } \\
\text { eklenirken yeni statüler de olușturulmuștur. Bu yıldan itibaren özellikle } 2007 \text { yılında sekizinci ve } \\
\text { dokuzuncu nesil yazarlar, sitenin yeni yazarları arasına eklenirken çaylak yazar statüsü eklenmiștir. } \\
\text { Bu yazarların, } 2008 \text { yıından itibaren satırbașı yazar olduğu görülür. Yukarıda da belirtildiği üzere } \\
\text { nesil hiyerarșisi } 2010 \text { yılında kaldırılmıștır. Bununla birlikte, yazarların ilk on mesajlarını ne zaman } \\
\text { girdiklerine ve daha önemlisi hesaplarına her gün giriș yapan kullanıcıların dağıımına göre yazar } \\
\text { adaylarının, çaylakların, onay sıralamasını etkilemektedir. }\end{array}$ \\
\hline
\end{tabular}

Sitenin yazar sıralaması ve farklı isimler altında yazarları değerlendirdiği uygulamalarının aslında düzenli bir kullanım ve daha önemlisi maddi olmayan emeğin sürekliliğini sağlamaya yönelik bir dizi önlem olarak dikkat çektiği söylenmelidir. Ancak yukarıda da açıklandığı üzere 2016 yılı hem Site hem de maddi olmayan emekçileri arasındaki ilişkilerin yeniden düzenlendiği, aslında kırılma olarak isimlendirilmesi daha doğru olacaktır, dönemi oluşturur. Dönem içerisinde tasarımı değişen ve klasik gri yerine beyaz arka fonun kullanıldığı bir site tasarımının yanı sıra, reklamsız görünümün artık olmaması ve kullanıcıların reklam süresini aşamaması, mesajlar arasındaki çizgilerin kalkması ve daha önemlisi sayfa içerisinde devam etmeyen mesajların ancak "devamını okuyayım" seçeneğinin işaretlenmesiyle okunabilmesi bu dönemin önemli değişimlerini oluşturmaktadır. Sözlük gerek tasarımı ve gerekse kullanıcıları ile yaptığı sözleşmeleri doğrultusunda oldukça anlamlı bir dizi değişim geçirirken yazarlarından keskin bir tepki alması ve önceki mesajların silinmesi aslında mülkiyet ve emek arasındaki diyalektiğinin farklı bir açıdan değerlendirilebilmesi için de özel bir kesit açmıştır. Gerçekten de 28 Şubat protestosunun ardından yazarlarının 
önemli bir bölümünü kaybeden Ekşi Sözlük yönetiminin, "yedek işgücü" olarak elinde var olan ve o güne değin yazarlık yaptırılmamış yazar adaylarını harekete geçirmesi, en azından iletişim çalışmalarındaki emek ve emeğin dönüşümüne dair tartışmaların yeniden ziyareti için oldukça anlamlıdır.

\section{Sonuc}

Türkiye'nin 28 Şubat 2016 tarihinde Ekşi Sözlük "direnişi” örneğinde yaşadığı süreç, gerçekte yeni enformasyon ve iletişim teknolojileri ile maddi olmayan emek arasındaki diyalektiğin çözümlenebileceği özel bir uzam oluşturmaktadır. Türkiye emek tarihi içerisinde ilk kez karşılaşılan yeni enformasyon ve iletişim teknolojilerinde emeğin direnişi gerçekten de iletişim araştırmaları ile emek araşındaki tartışmanın bu kez somut bir deneyim alanı içerisinde de tartışılabilmesine olanak sunmaktadır. Bu çalışmanın gerçekleştirilebilmesi için iki güçlü varsayımın değerlendirilebileceği özel bir kesit sunan 28 Şubat 2016 tarihindeki Ekşi Sözlük "direnişi” bu bağlamda yalnızca bu çalışma için değil daha da kapsayıcı bir biçimde maddi emeğe ve emeğin dönüşümüne dair bütün çalışmalar için de özel bir uğrak sunmaktadır. Emeğin çözümlenebilmesi için kapitalist sermaye birikiminin yalnızca bir evresinin değil aksine bütün bir tarihinin okunmasına ilişkin çağrı, bu çalışmanın henüz giriş kısmında yer edinmişti. Emeğin çözümlenebilmesi için, emeğin ancak üretim güçleri ve ilişkileri arasında belirlenmiş daha bütünlüklü bir çözümleme düzeyine intiyaç duyduğuna dair varsayım ise çalışmanın bütününe yayılmış hatta bu çalışma tam da böylesi bir varsayım üzerinde kurulmuştu. Gerçekten de Ekşi Sözlük yönetiminin, yazarlarına önceden bilgi verme "gereği" dahi duymaksızın sözleşmesindeki değişimi, Guy Standing'in (2014:19), kırılgan, içi vasıfsızlaştırılmış hatta bu çalışma boyunca tartışıldığı gibi kendi emeğine gittikçe yabancılaştırılmış yeni ve "tehlikeli" bir sınıfı (prekarya) işaret ettiği kadar, kapitalist sermaye birikiminin kendi içerisindeki sürekliliğini de yeniden üretmiş değil midir? Böylesi bir sürecin ancak kapitalizmin yeni bir aşamasına işaret ettiğini belirlemek, her ne kadar araştırmacı için, özel bağlamlar içerisinde tartışmaları sınırlandırabilmek yönünde güvenceli bir alan sunsa da aslında kapitalizmin tüm dönemlerinde emek üzerinden genişlettiği sermaye birikiminin, ilkel birikimin, son evresi olarak ele alınabilmesi daha tutarlı bir bütünlük sunmamakta mıdır? Gerçekten de Foucault (2008:219) insan sermayesinin henüz ekonomik olarak yeterince keşfedilmemiş yeni bir toprağı hatta bir madeni işaret ettiğini söylerken, gerçekte en azından iki önemli süreci birlikte vurgulamaktaydı. Bu süreçlerin ilki, ekonomik ilişkilerin daha önce keşfedilmemiş bir alana doğru genişlemesidir ki maddi olmayan emek tam da böylesi bir genişleme için anlamlı bir uğrak oluşturmaktadır. Foucault'un işaret ettiği ikinci süreç, yine maddi olmayan emek kavramını bu kez yine daha önce ekonomik olmadığı düşünülen bütün bir alanın, ekonomiye dair güçlü bir eleştirinin merkezinde olması gerekliliğidir ki böylesi bir gereklilik zaten maddi olmayan emeğin, geleneksel değer teorilerinin de yeniden ele alınması gereken yeni "keşfedilmemiş" alanlarını oluşturmaktadır. Böylesi bir "keşfedilmemiş" alan olarak maddi olmayan emek düşüncesinin gittikçe ve üstelik tek boyutlu bir açıdan, kapitalizmin birikim rejimi içerisindeki "yeni” bir aşamanın değil bütün bir tarihi içerisindeki toplumsal ilişkiler ağının, sermaye ve emek arasındaki eşitsiz diyalektiğin ve ilkel olmasının ötesinde gittikçe vahşileşen bir kapitalizmin inşası olarak değerlendirilmesi gerekir. Bu çalışmanın henüz giriş kısmından itibaren belirtildiği gibi sosyal medya ağları, kapitalizmin yeni bir birikim aşamasından daha çok tam da kapitalizmin toplumsal ilişkiler ağı içerisinde üretilmiş ve denetim toplumundan, disiplin toplumuna doğru önemli bir toplumsal dönüşüm ile 
örülmüş bir yapıyı görünür kılmaktadır. Zygmunt Bauman ve David Lyon (2016:15) böylesi bir yapıyı, "akışkan gözetim" ve sosyal medya ağlarını ise akışkan gözetimin araçsallaştırdığı bir yapı olarak değerlendirirler. Bauman ve Lyon; "sosyal medyanın varlığı, kullanıcıların izlenmesine ve edinilen bilgilerin diğerlerine satılmasına bağlıdır. Sosyal medyanın direniş için sunduğu olanaklar çekici ve bazı açılardan da yararlı olabilir; fakat gittikçe akıcılaşmakta olan bir dünyada kalıcı ilișkiler kurabilmek için gerekli koşulların olmaması ve sosyal medya içerisindeki gözetim gücünün yerleşik ve etkili olması nedeniyle aynı zamanda da kısıtıdır" demektedir. Bu çalışmanın henüz başında, sosyal medya ağlarının anlamlandırılabilmesi için üstelik bizatihi kendisi oldukça sınırlı olarak ilgilenmişken Bourdieu sosyolojisine yeniden dönülmesi gerektiği çünkü kullanıcı için ön denetimli, keskin olarak belirlenmiş ve sınırlı bir alan olarak sosyal medya ağlarının öne çıktığı belirtilmişti. Çünkü kullanıcısı için keskin hatlarıyla belirlenmiş ancak böylesi bir alan içerisinde oluşan habitusun, maddi olmayan emeği bir mübadele değeri içerisinde belirlemesi oldukça anlaşılır olsa gerektir. Gerçekten de böylesi bir medyanın, tıpkı Ekşi Sözlük örneğinde daha net olarak gözlenebileceği gibi, yeni bir mübadele değeri olarak bu kez doğrudan maddi olmayan emeğin birikim için araçsallaştırılmasının kaçınılmaz olduğu belirtilmelidir. Ancak bu çalışma, maddi emeğe dair çalışmalardan farklı olarak, yeni enformasyon ve iletişim teknolojilerindeki böylesi bir emeği çözümlerken, tarihsel bir sistem olarak kapitalizmin emeğe dair rolünü yine özgün tarihselliği içerisinde ele alınması gerektiğini öne sürmektedir.

Maddi olmayan emek ve kapitalizm arasındaki diyalektiğin çözümlenmesine dair çabanın, ya da daha farklı söylendiğinde yeni bağlamlarında kadim sorunların tartışılmasının, iki neden doğrultusunda anlamlı olduğu belirtilmelidir. Illk neden; mülkiyet, emek ve iktidar arasındaki diyalektiğin çözümlenmesinin daha genel bir toplumsal sistem eleştirisi ile bütünleştirilebilmesidir ki, bu doğrultuda sermaye ve emek arasındaki ilişkinin çözümlenebilmesi en azından sözü edilen ilişki ağının tarihsel bir bağlam içerisinde ele alınabilmesini sağlamaktadır. Gerçekten de; iletişim çalışmalarının, özellikle Türkiye'de uzun bir süredir unutulmuş görünen, Marksist siyasal iktisat içerisinde kurulan tartışmalara yeniden dönmesinin, "heyecanlı" tartışmalar içerisinden kurulacak ve medyanın gerçekte nasıl işlediğine dair anlamlı bir çerçeveye ihtiyacının olduğu düşünülmektedir. Bu kesit içerisinde, Jernej Prodnik (2014:357) ile birlikte düşünüldüğünde "burada bizi ilgilendirmesi gereken asıl şey, sermayenin emek olarak neyi gördüğüdür". Prodnik'in söz konusu belirlemesine bir ekleme de, medya mülkiyetinin maddi olmayan emeği, maddi birikim için nasıl işe koştuğudur sorusu üzerinden yapılmalıdır. Yeni enformasyon ve iletişim teknolojilerinin geniş bir parantez içerisine aldığı, ancak tam da bu yönüyle gittikçe görünür kılmaktan da uzaklaştırdığı, kullanıcı emeğinin çözümlenebilmesine dair bir çabanın tam da söz konusu iki belirleme üzerinden harekete geçmesi gerekmektedir. Böylesi bir "gereklilik" aslında genel bir toplumsal sistem analizinin, bu çalışma içerisinde yapılmasının amaçlandığı gibi, medyanın gündelik pratikleri içerisine yerleştirilmesini ya da bir bağ kurulabilmesini sağlayacaktır. Ancak yukarıda söz edildiği gibi bu çalışmanın yapılmasındaki ikinci neden, somut bir analiz üzerinden medyanın üretim dizgesinde emeğin nasıl konumlandığını çözümlemektir ki medyanın çoğu kez gizlediği ve görünür kılmaktan uzaklaştırdığı sermaye ile emek arasındaki diyalektiğin analizinin aslında iletişim çalışmaları için henüz söyleyebileceği çok sözünün olduğunu vurgulamayı amaçlamaktadır. Çalışmanın önceki kısımlarında tartışıldığı gibi, geleneksel medya biçiminden yeni enformasyon ve iletişim teknolojilerine değin genişleyen tarihsel kesit içerisinde medyanın üretim ilişkilerinin hem ihtiyaç duyduğu ancak hem de görünür 
kılmaktan uzaklaştığı maddi olmayan emeğin, sermaye birikim sürecine nasıl ve hangi koşullarda dâhil edildiğini çözümleyebilmek tam da bu nedenle önem taşımaktadır. Üstelik kapitalizmin yeni bir aşamasına geçtiğinin bu kez sermaye birikiminin enformasyon üzerinden sağlandığının iddia edildiği "yeni" kapitalizm döneminin nasıl da çelişkili bir süreklilik oluşturduğunu anlamlandırmanın bu doğrultuda, hem önemli hem de kaçınılmaz bir tartışma geleneğini yine geniş bir parantez içerisine aldığı söylenmelidir. Böylesi bir tartışma, her ne kadar, Türkiye'nin ilk sosyal paylaşım siteleri arasında yer alan Ekşi Sözlük üzerinden gerçekleştirilmiş olsa da sermaye ve emek arasındaki ilişkinin diğer örneklere de genişletilebileceği açıktır.

Çalışma içerisinde, kapitalizmin yeni olduğu söylenen biçimlerinin nasıl da klasik bir denetim olarak öne çıktığını, maddi olmayan emeğin de her kertesinde "iyi" tasarlanmış bir alana çekildiğini ve denetlendiğini belirlemek bu bağlamda önem taşımaktadır. Gerçekten de yeni enformasyon ve iletişim teknolojilerinin, çoğu kez geçerli ve güçlü bir veriye dayanmaksızın, "özgürlük alanı” üzerinden metalaştırılmasının aksine gerçekte kontrol edilen, denetlenen ve mülkiyetin çıkarları ile bütünleşen alanlar olduğunu söylemek ve bu iddiayı somut bir analiz üzerine temellendirebilmek anlamlı bir çaba olsa gerektir. Gerçekten de kapitalizmin emek üzerinde ancak tam da sermayenin birikim koşulları içerindeki gerçekleştirdiği yeniden yapılandırma gücü birbirinden çok da kolay ayrımlaştırılabilecek bir odağı değil aksine birbiri içerisinde zaten yer edinmiş bir anlatıyı çözümleme çabasını gerektirmektedir. Bu açıdan, ilkel sermaye birikiminin yeni enformasyon ve iletişim teknolojilerindeki sürekliliğini değerlendirmek ve emeğin maddi olmayan biçimini yalnızca söylemin belirlediği bir kısıt olarak değil aksine bir praksis olarak değerlendirmek önemlidir. Bu çalışma içerisinde, çalışmanın tartışma izleği içerisinde tartışılamayan bir unsura daha değinmek gerekir. Gerçekten de, sermayenin emek ile kurduğu diyalektiğin, çoğu kez emeğin direnişine, en azından tartışma düzeyinde dahi olsa dön(e)mediği görülür. Ekşi Sözlük direnişinin son döneminde, Mart 2016 tarihinde, maddi olmayan emeğin Site yönetimine "geri adım" attırması (http://www.cumhuriyet.com.tr) ve son kertede emeğin, üretimin kazanması önemli bir gelişme olmasına rağmen 690.000 mesajın silinmesi böylesi bir başarıyı gölgelemektedir. Yeni enformasyon ve iletişim teknolojilerini, sıklıkla bir "devrim" olarak değerlendiren görüşlerin ötesine geçerek, kapitalizmin intiyaç duyduğu sermaye birikim sürecini kendi içerisinde çelişkili olmakla birlikte bir süreklilik içerisinde değerlendiren çalışmalara ve çabalara tam da bu yönüyle intiyaç duyulmaktadır.

\section{Kaynakça}

Başaran, Funda (2005). “Internetin Ekonomi Politiği”. İnternet, Toplum, Kültür içinde. Der: Mutlu Binark ve Barış Kılıçbay.

Başaran, Funda (2014). "Giriş: Marx, Medya, Meta ve Sermaye Birikimi". Medya, Meta ve Sermaye Birikimi: Marx Geri Döndü içinde. Türkçe Yayının Derleyeni: Funda Başaran. Ankara: Nota Bene Yayınları. 11-20.

Bauman, Zygmunt, LYON, David (2016). Akışkan Gözetim. Çev: Elçin Yılmaz. İstanbul: Ayrıntı Yayınları.

Budak, Özgür (2015). Türkiye'de Kapitalist Yönetici Sınıfı. İstanbul: Ayrıntı Yayınları. 
Caraway, Brett (2011). "Audiance Labor in the New Media Environment: A Marxian Revisiting of the Audiance Commodity". Media, Culture and Society. Vol: 33(5). 693-708.

Castells, Manuel (2013). İsyan ve Umut Ağları: İnternet Çağında Toplumsal Hareketler. Çev: Ebru Kılıç. İstanbul: Koç Üniversitesi Yayınları.

Cohen, S. Nicole (2014). "Bir Mücadele Alanı Olarak Kültürel İş: Freelance Çalışanlar ve Sömürü”. Çev: Gökçe Baydar. Medya, Meta ve Sermaye Birikimi: Marks Geri Döndü. Der: Vincent Mosco ve Christian Fuchs. Türkçe Yayının Derleyeni: Funda Başaran. Çev: Zafer Kıyan. İstanbul: Nota Bene Yayınları. 45-81.

Çeğin, Güney, Göker, Emrah ve Ökten, Nazlı (2014). "Cogito'dan : Özerk ve Müdahil Bir Sosyal Bilim İçin”. Cogito Üç Aylık Düşünce Dergisi. Yıl: 2014, Sayı: Bahar 76. İstanbul: Yapı Kredi Yayınları. 5-7.

Dağdaş, Erdal ve Yıldız, Mehmet Emir (2015). “Türkiye'de İzleyicinin Metalaşması: Televizyon Dizilerinin Sosyal Reyting Ölçümlerinin Eleştirel Ekonomi Politik Çözümlemesi”. Global Media Journal TR. Edition. Vol: 5(10). 120-142.

Daubs, S. Michael (2015). "The Social News Networks: The Appropriation of Community Labour in CNN's iReport". International Association for Media and Communication Research: The Political Economy of Communication. Vol: 3(2). 55-73.

Doğu, Burak, Ziraman, Zehra ve Ziraman, Emrah, D. (2016). "Web Based Authorship in the Context of User Generated Content, An Analysis of a Turkish Web Site: Eksi Sozluk. http.//www. resarchgate.net.Erişim Tarihi: 09.12.2016. Saati: 21:41. 1-23.

Ekman, Mattias (2014). "Birikimi Anlamak: Marx'ın İlkel Birikim Kuramı'nın Medya ve İletişim Çalışmaları Açısından Önemi”. Medya, Meta ve Sermaye Birikimi: Marks Geri Döndü. Der: Vincent Mosco ve Christian Fuchs. Türkçe Yayının Derleyeni: Funda Başaran. Çev: Zafer Kıyan. İstanbul: Nota Bene Yayınları. 83-118.

Fast, Karin, ÖRNERBRIGN, Henrik ve Karlsson, Michael (2016). "Metaphors of Free Labor: A Typology of Unpaid Work in the Media Sector". Media, Culture \&Society. 1-16.

Federici, Silvia (2014). "Duygulanımsal Emek Üzerine”. Çev: Çağdaş Gümüşoluk. Bilişsel Kapitalizm: Eğitim ve Dijital Emek. Ed: Michael A. Peters ve Ergin Bulut. İstanbul: Nota Bene Yayınları.

Fisher, Eran (2014). "Daha Az Yabancılaşma, Nasıl Daha Fazla Sömürü Yaratır? Sosyal Paylaşım Sitelerinde İzleyici Emeği”. Medya, Meta ve Sermaye Birikimi: Marks Geri Döndü. Der: Vincent Mosco ve Christian Fuchs. Türkçe Yayının Derleyeni: Funda Başaran. Çev: Gökçe Baydar. İstanbul: Nota Bene Yayınları. 119-150.

Foucault, Michael (2008). The Birth of Biopolitics. Çev: Graham Burchell. New York: Palgrave Publishing.

Fuchs, Christian (2014a). "Digital Prosumption Labour on Social Media in the Context of the Capitalist Regime of Time". Time\&Society. Vol: 23(1). 97-123. 
Fuchs, Christian (2014b). "Bilişsel Kapitalizm ya da Enformasyonel Kapitalizm? Enformasyonel Kapitalizmde Sınıfın Rolü”. Bilişsel Kapitalizm: Eğitim ve Dijital Emek. Ed: Michael A. Peters ve Ergin Bulut. Türkçe Yayına Hazırlayan: Diyar Saraçoğlu. İstanbul: Nota Bene Yayınları. 137-189.

Fuchs, Christian (2015). Dijital Emek ve Karl Marx. Çev: Tahir Emre Kalaycı ve Senem Oğuz. İstanbul: Nota Bene Yayınları.

Fuchs, Christian (2016). Sosyal Medya: Eleştirel Bir Giriş. Çev: Diyar Saraçoğlu ve İlker Kalaycı. İstanbul: Nota Bene Yayınları.

Fuchs, Christian ve Mosco, Vincent (2014). "Marks Geri Döndü: Günümüzde Eleştirel İletişim Çalışmalarında Marksist Kuram ve Araştırmanın Önemi”. Çev: Funda Başaran. Ankara: Nota Bene Yayınları. 21-43.

Fuchs, Christian ve Witheford, Dyer Nick (2013). "Karl Marx@Internet Studies". New Media Society. Vol: 15(5). 782-796.

Gerlitz, Caroline ve Helmond, Anne (2013). "The Like Economy: Social Buttons and the DataIntensive Web". New Media\&Society. Vol: 15(8). 1348-1365.

Hallikainen, Petri (2014). "Why People Use Social Media Platforms: Exploring the Motivations and Consequences of Use". From Information to Smart Society: Environments, Politics and Economics.Lecture Note in Information Systems and Organizations. içinde. Ed: Lapo Mola, Ferdianda Pennorola, Stephano Za. Roma: Springer Publication. 9-17.

Henning, William ve Hebblewhite, James (2014). “Üretim Araçları Olarak İletişim Araçları”. Medya, Meta ve Sermaye Birikimi: M@rx Geri Döndü. Der: Vincent Mosco ve Christian Fuchs. Türkçe Yayının Derleyeni: Funda Başaran. Çev: Zeynep Saygın Sarbay. Ankara: Nota Bene. 193-216.

Hesmondhalgh, David (2010). "User Generated Content, Free Labour and the Cultural Industries". Ephemera: Theory\& Politics in Organization. Vol: 10(3/4). 267-284.

http://www.cumhuriyet.com.tr (2016). "Ekşi Sözlük'te İsyan Büyüdü, Yönetim Geri Adım Attı”. Erişim Tarihi: 09.12.2016. Saati: 21.43.

http://www.cumhuriyet.com.tr (2016). “Ekşi Sözlük’te İsyan: Direniş Başladı”. Erişim Tarihi: 29.02.2016, Saati: 14:15

http://www.eksisozluk.com./giris (2016). "Ekşi Sözlük Sitesi Giriş Ekranı". Erişim Tarihi: 12.03.2016. Erişim Saati: 10:48.

http://www.eksisozluk.com/eksi-sozluk-kullanıcı-sozlesmesi (2016). "Ekşi Sözlük Kullanıcı Sözleşmesi”. Erişim Tarihi: 13.04.2016. Erişim Saati: 11:06.

http://www.radikal.com.tr (2016). “Ekşi Sözlük’te Binlerce Entry Silindi”. Erişim Tarihi: 25.04.2016. Erişim Saati: 14:02.

http://www.tr.wikipedia.org (2016). "Ekşi Sözlük". Erişim Tarihi: 28.04.2016. Erişim Saati: 13:53. Kıyan, Zafer (2015). "Dijital Kapitalizmin İletişim Alanındaki İzleri: Üretim, Dolaşım, Emek ve 
Tüketim Süreçleri”. Toplum ve Bilim. Sayı: 135. 27-57.

Kıyan, Zafer (2015). "Dijital Kapitalizmin İletişim Alanındaki İzleri: Üretim, Dolaşım, Emek ve Tüketim Süreçleri”. Toplum ve Bilim. Sayı: 135. 27-57.

Manzerolle, R. Vincent ve KJOSEN, Atle Mikkola (2014). "Sermayenin Iletişimi: Sayısal Medya ve Hızlanmanın Mantığı”. Medya, Meta ve Sermaye Birikimi: Marks Geri Döndü. Der: Vincent Mosco ve Christian Fuchs. Türkçe Yayının Derleyeni: Funda Başaran. Çev: Banu Durdağ. İstanbul: Nota Bene Yayınları. 217-253.

Marks, Karl (2013). Kapital. Cilt: 1. Çev: Mehmet Selik ve Nail Satlıgan. İstanbul: Yordam Kitap.

Mcchesney, Robert Waterman (2007). Communication Revolution. New York: New Press.

Nixon, Brice (2016). "The Old Media Business in the New: the Googlization of Everything as the Capitalization of Digital Consumption". Media, Culture \& Society. Vol: 38(2). 212-231.

Özmakas, Utku (2015). "İnsan Sermayesinin Kaynağı: Maddi Olmayan Emek”. Toplum ve Bilim. Sayı: $135.8-27$.

Piketty, Thomas (2014). Yirmi birinci Yüzyılda Kapital. Çev: Hande Koçak. İstanbul: Türkiye İş Bankası Yayınları.

Prey, Robert (2014). "Ağın Kör Noktası: Dışlama, Sömürü ve Marx’ın Süreç-lilişkisel Ontolojisi”. Çev: Hakan Yüksel. Medya, Meta ve Sermaye Birikimi: Marks Geri Döndü. Der: Vincent Mosco ve Christian Fuchs. Türkçe Yayının Derleyeni: Funda Başaran. Çev: Zafer Kıyan. İstanbul: Nota Bene Yayınları. 255-300.

Prodnik, Jernej (2014). "Sürüp Giden Metalaştırma Süreçleri Üzerine Bir Not: İzleyici Metasından Toplumsal Fabrikaya”. Çev: Zafer Kıyan. Medya, Meta ve Sermaye Birikimi: Marks Geri Döndü. Der: Vincent Mosco ve Christian Fuchs. Türkçe Yayının Derleyeni: Funda Başaran. Çev: Zafer Kıyan. İstanbul: Nota Bene Yayınları. 301-367.

Romele, Alberto ve Severo, Marta (2016). "The Economy of the Digital Gift: From Socialism to Sociality Online". Theory, Culture \& Society. Vol: 0(0). 1-21.

Standing, Guy (2014). Prekarya: Yeni Tehlikeli Sınıf. Çev: Ergin Bulut. İstanbul: İletişim Yayınları. Tondeur, Jo, Sinnaeve, İlse, Houtte, van Mieke, Braak, van Johan (2010). "ICT as Cultural Capital: The Relationship Between Socioeconomic Status and the Computer-Use Profile of Young People". New Media and Society. Vol: 13(1). 151-168.

Toscano, Alberto (2007). "From Pin Factories to Gold Farmers: Editorial Introduction to a Research Stream on Cognitive Capitalism, Immaterial Labour and the General Intellect". Historical Metarialism. Vol: 15. 3-11.

Wacquant, Loic (2014). "Simgesel İktidar ve Grup Oluşumu: Pierre Bourdieu'nün Sınıfı Yeniden Çerçevelemesi Üzerine”. Cogito: Yapı Kredi Yayınları-Üç Aylık Düşünce Dergisi-Sayı: 76. 204230. 
Wayne, Mike (2009). Marksizm ve Medya Araştırmaları: Anahtar Kavramlar, Çağdaş Eğilimler. Çev: Barış Cezar. İstanbul: Yordam Yayınları.

Zheng, Rong, Jiexun, Li, Hsinchun, Chen, Huang, Zan (2006). "A Framework for Authorship Identification of Online Messages: Writing Stlye Features and Classification Techniques". Journal of the American Society for Information Science and Technology. Vol: 57(3). 378-393.

\section{Notlar}

1 Bourdieu'nun çalışmalarının, ağırlıklı olarak, 1960 ve 1970'li yıllar boyunca gerçekleşmesi ve odağını savaş sonrası dönemde, eğitimde demokratikleşmenin oluşturduğu ilginin değerlendirilmesi (Tondeur, Sinnaeve, Houtte ve Braak, 2010:154) oluşturduğu için teknoloji ile oldukça sınırlı olarak ilgilendiği söylenmelidir. Türkiye'de de süre giden iletişim çalışmaları içerisinde, Bourdieu sosyolojisine dair ilginin çok daha sınırlı ancak genişleyen bir ilginin varlığından söz edilmelidir. Özel Sayının editörleri Güney Çeğin, Emrah Göker ve Nazlı Ökten (2014:7) amaçlarını şöyle açıklar: "bu sayının en temel avantajlarından biri, hem Bourdieu ile uzun zamandır hemhal olanlara hem de Bourdieu ile tanışıklığı yeni başlayacak olan okurlara, Bourdieu'nün çalışıı̆ı sahaların kapsayıcıı̆ğını takdim ederek, akademik disiplinler ayrışmasının sorgulanması için ciddi soruşturma patikaları vermesidir". Özel sayı içerisinde Özgür Budak (2015:24) Bourdieu'nun araştırma programını; "miras alınmış zenginlik ve gücün dağılımı olarak tanımlanan varoluş koşullarıyla, kültürel yetkinlik, ahlaki tutarlılık, kişisel gelişimle somutlaşan toplumsal failin aldığı pozisyonlar arasındaki üretken ilişkiyi merkeze koymaktadır" olarak açıklamaktadır.

2 Christian Fuchs (2015:151-153) her ne kadar "üretüketici" (prosummer) terimini kullansa da aslında İngilizcenin yapısal özelliklerinin olanak sunması ile önemli bir birleştirmeyi gerçekleştirmiştir. Bu çalışmada ise, hem Türkçe'nin yapısal nitelikleri hem de aslında bir devamlılığı vurgulamak için, "üreten tüketici" terimi tercih edilmiştir.

3 Cumhuriyet Gazetesi'nde yer alan habere göre, Türkiye'nin en çok ziyaret edilen siteleri arasında yer alan, sosyal paylaşım sitesi, Ekşi Sözlüğün 28 Şubat 2016 tarihinden itibaren üstelik site yazarlarına bilgi verilmeksizin yeni bir temaya geçmesi site yazarlarının tepkisine yol açmıştır. Böylesi bir tepki sitenin 500'ün üzerinden yazarın aralarında örgütlenerek, "28 Şubat 2016 Ekşi Sözlük Direnişi” temalı bir direnişine yol açmıştır (http://www.cumhuriyet.com.tr (2016). "Ekşi Sözlük’te İsyan: Direniş Başladı". Erişim Tarihi: 29.02.2016, Saati: 14:15).

4 Negri'nin tartışması artık bizatihi işin, kendisine ayrılmış özerk mekânlarda (fabrikalarda) değil bütün bir toplumsal yaşam pratiklerine (toplumsal fabrika) yayılmasıdır. Toplumsal fabrika içerisinde emek, yayılmış ve merkezsizleşmiştir.

5 Carolin Gerlitz ve Anne Helmond (2013:1350), internetin erken dönemlerinde, Web 1.0, "herkes için bir enformasyon kaynağı” olarak konumlandığını ancak Web 2.0'a doğru yaşanan dönüşümün bu kez "bir paylaşım platformu olarak internet" alt yapısını ortaya çıkarttığını belirler.

6 Zizek 2008 yılında dünya ekonomisinin büyük krizinin ardından Marksist politik iktisat tartışmalarının da önemli ölçüde genişlediğini aslında tam da böylesi bir kesit üzerinden açıklamaktadır (aktaran Fuchs ve Witheford, 2013:15). Bu açıdan Robert McChesney'in (2007:5557); yeni iletişim ve enformasyon teknolojilerine dair Marksist yorumların aslında iletişimin yeniden düşünülmesine dair araçları zaten sağladığı yönündeki belirlemesi oldukça önemlidir 
7 Halen British Museum'da sergilenen Rosetta ya da Reşit Taşı; Batı açısından ötekinin dilini anlamada anahtar özelliği niteliği ile temsili bir nitelik taşıyan taştır. Çözümlenmesi zor bir gizemi aydınlatmak için kullanılan en önemli ipucu anlamında da kullanılmaktadır (Henning ve Hebblewhite, 2014:195).

88 Mart 2016 tarihinde, "Ekşi Sözlük'te Binlerce Entry Silindi” manşeti ile haberini duyururken 340 site yazarının 234000 adet mesajını sildiğini belirtir. Eylemlerin son döneminde ise, sonuç kısmında da yer aldığı üzere, 690.000 mesaj silinmiştir. 